\title{
The World System and the Hollowing Out of State Capacity: How Structural Adjustment Programs Affect Bureaucratic Quality in Developing Countries ${ }^{1}$
}

\author{
Bernhard Reinsberg \\ University of Cambridge
}

Alexander Kentikelenis

Bocconi University
Thomas Stubbs

Royal Holloway

Lawrence King

University of Massachusetts

The administrative ability of the state to deliver effective policy is essential for economic development. While sociologists have long devoted attention to domestic forces underpinning state capacity, the authors focus on world system pressures from Western-dominated international organizations. Scrutinizing policy reforms mandated by the International Monetary Fund (IMF), the authors argue that "structural conditions" exert deleterious effects on bureaucratic quality by increasing the risk of bureaucrats falling prey to special interests and narrowing potential policy instruments available to them. The authors test these arguments using a new data set on IMF conditionality from 1985 to 2014. Their analysis shows that structural conditions - especially conditions on privatization, price deregulation, and public sector employment-reduce bureaucratic quality. Using instrumentation techniques, the authors also discount the possibility that the relationship is driven by the IMF imposing structural conditions precisely in countries with low bureaucratic quality. A careful reconsideration of IMF policy reforms is therefore required to avoid undermining local institutions.

The administrative ability of the state to design and implement effective policy is an essential condition for economic development (Amsden 1989; Wade

\footnotetext{
${ }^{1}$ We thank Timon Forster, Hector Rivera, Stefanie Walter, and Sebastian Ziaja for helpful comments. Funding by the University of Cambridge (Centre for Business Research
}

(C) 2019 by The University of Chicago. All rights reserved. 0002-9602/2019/12404-0006\$10.00 
1990; Evans 1995; Evans and Rauch 1999; Kohli 2004; Mazzucato 2015). Drawing on the work of Max Weber, sociologists have suggested several pathways underpinning the development of capable bureaucracies. One perspective posits that cultural factors - like a Protestant work ethic - are important for determinants of state capacity development, by commanding citizens' obedience (Weber 1930; Anderson 1991; Gorski 1993). Others emphasize the role of economic modernization, contending that industrial societies - unlike agrarian ones - have more complex needs best addressed by a central state (Smelser 1964; Gellner 1983; Geddes 1994). The resource needs of warfare also drive many countries to discipline state officers, thereby developing a functioning bureaucracy (Tilly 1990; Mann 1995; Hechter 2000).

Scholarship in global and transnational sociology has also elaborated on the ways in which international forces affect the capabilities of states. First, mimetic and normative isomorphism results in the gradual spread of policy scripts that circulate transnationally, as states adopt and adapt them to suit their purposes (DiMaggio and Powell 1991; Meyer et al. 1997; Drori and Meyer 2006; Chorev 2012; Pinheiro, Chwieroth, and Hicks 2015). For example, Hwang (2006) shows the worldwide rise of national development plans in the postwar era, following dominant norms in the world polity on state planning. In contrast to the soft and slow normative-isomorphic processes, world systems and dependency theories emphasize structural inequalities inherent to contemporary globalization (Wallerstein 1974; Cardoso and Faletto 1979; Chase-Dunn 1998). Within this framework, powerful intergovernmental organizations - like the European Union or the World Bankare central actors that undergird and perpetuate the dependency of "peripheral" nations (developing countries) on the capitalist "core" (e.g., Hanley, King, and Tóth 2002; Panitch and Gindin 2012). To do so, these organizations make their financial or technical support to developing countries conditional on the introduction of certain reforms that - explicitly or implicitly-favor the interests of the West and weaken bureaucratic quality (Hamm, King, and Stuckler 2012; Ban 2016).

In this article, we build a theoretical and empirical bridge between world systems theory and the Weberian-inspired political sociology arguments on state capacity. While these two strands of scholarship have hitherto developed in little dialogue, we argue that their insights can be fruitfully combined to develop a distinctive global and transnational sociological perspective on the determinants of state capacity. Our analysis focuses on the activities of the International Monetary Fund (IMF) — one of the world's most powerful international organizations - which has been able to set the

and Cambridge Political Economy Society Trust) is gratefully acknowledged. Direct correspondence to Bernhard Reinsberg, Centre for Business Research, 12 Trumpington Street, Cambridge CB2 1QA, United Kingdom. E-mail: br385@cam.ac.uk 
broad parameters of economic reform in the developing world (Halliday and Carruthers 2007, 2009; Kentikelenis and Seabrooke 2017). This power stems from the organization's systemic role in upholding global financial stability, which endows it with extensive resources and an unrivaled position as a global lender of last resort. Through the practice of "conditionality," the IMF can mandate far-reaching policy changes, including the overhaul of state administrations (Babb and Carruthers 2008). The IMF contends that such policies are necessary for securing macroeconomic stability (Khan and Knight 1983), while critics point to devastating and counterproductive effects on developing countries (Babb 2005; Evans and Sewell 2013; Sassen 2014). For example, IMF programs have been linked to the retrenchment of public services, the dismantlement of state bureaucracies, and civil unrest (Walton and Ragin 1990; Hanley et al. 2002; King and Sznajder 2006).

A major shortcoming of this scholarship is that IMF lending programsthe main mechanism by which this prototypical Western-dominated multilateral organization shapes peripheral states - are generally treated as "black boxes": it is assumed that they all contain a similar set of promarket and antistate reforms that devastate public sectors. We question the merits of this simple narrative. Using new data on conditionality, we examine the extent to which distinct components of IMF programs have a differential impact on bureaucratic quality. In particular, we distinguish between two types of IMF conditionality: structural conditions, or intrusive reforms that seek to transform countries' political economies via deregulation, liberalization, and privatization; and stabilization conditions, which are less intrusive broad targets on macroeconomic indicators intended to reduce balance-of-payments deficits (Polak 1991; Toye 1994; Vreeland 2007; Dreher 2009; Woo 2013). We posit that structural conditions diminish the ability of states to recruit, train, and retain qualified personnel, and so we expect them to reduce bureaucratic quality.

Empirically, we study the effects of IMF conditionality on state capacity in developing countries from 1985 to 2014. Using data from the International Country Risk Guide as a measure of bureaucratic quality, we find that structural conditions reduce bureaucratic quality and that stabilization conditions exert no significant effect. Further analysis reveals that, more specifically, conditions that require privatization of state-owned enterprises, lifting of price regulations, and reductions in the number or wages of civil servants underlie the negative effect of structural conditions. In addition, using data from the Business Environment and Enterprise Performance Surveys, we find that firms experience more bribery by public officials when countries under IMF programs face more structural conditions. Our results are significant even after accounting for nonrandom selection into IMF programs and the potential endogeneity of conditionality. Confidence in our 
findings is also bolstered by the fact that they are consistent across both perception- and experience-based measures of bureaucratic quality.

By casting light on the erstwhile undertheorized relationship between state capacity and world systems and dependency theories, our article integrates previously disparate insights from national-level political-sociological arguments (e.g., Skocpol 1979; Mann 1986; Evans and Rauch 1999) and global and transnational sociology (e.g., Hanley et al. 2002; King and Sznajder 2006; Li and Hicks 2016). In doing so, we document how the dynamics of political-bureaucratic development are inextricably linked not only to broad global forces (like trade or war) but also to specific global actors: organizations - whether intergovernmental, nongovernmental, or private - that diffuse cultural scripts of legitimate state structure. Such scripts can entrench the rationalities of global capitalism (Kentikelenis and Seabrooke 2017), with profound implications for the developmental trajectories of low- and middleincome countries.

Our findings also contribute to other branches of social scientific inquiry on state capacity, including political science (e.g., Hendrix 2010; FortinRittberger 2014; Cingolani, Thomsson, and de Crombrugghe 2015) and economics (e.g., Bräutigam and Knack 2004; Rodrik, Subramanian, and Trebbi 2004; Kaufmann, Kraay, and Mastruzzi 2008; Broich, Szirmai, and Thomsson 2015). To our knowledge, we present the first systematic inquiry into the effects of IMF conditionality on state capacity. Further, we contribute to sociologically informed policy debates by demonstrating the malleability of state capacity within a shorter time horizon than sociologists have come to expect based on earlier research. Finally, we offer methodological contributions to studies on the consequences of reform programs mandated by international organizations. In using a compound instrumentation technique to account for endogeneity of conditionality, our estimates lend themselves to causal interpretation, while other interpretations - for example, that countries with weak state capacity might receive systematically different conditions - can be ruled out.

\section{STATE CAPACITY, BUREAUCRATIC QUALITY, AND THE WORLD SYSTEM}

\section{Bureaucratic Quality as a Key Ingredient of State Capacity}

Sociologists have long recognized that capable states require professional bureaucracies - characterized by legal rationality, hierarchical organization, and incorruptible staff — committed to delivering high-quality public services (Weber 1978; Skocpol 1979; Mann 1986). In their seminal article, Evans and Rauch (1999) unpack "Weberianness" as a synonym for bureaucratic quality, comprising meritocratic staffing, professional training, long-term 
career opportunities in the public sector, competitive salaries, and performancebased rewards. Using surveys to collect information on these variables for 35 countries, they find that Weberianness positively correlates with economic growth. More recently, researchers from the Quality of Government Institute assembled an expert-survey data set on the structure of public bureaucracies for 159 countries, covering three dimensions of bureaucratic quality: professionalization, openness, and impartiality (Dahlström et al. 2015). Using these data, Nistotskaya and Cingolani (2016) show that countries in which bureaucracies are more insulated from day-to-day oversight by individual politicians have more effective business regulation and higher rates of business entry. Teorell (2015) finds that having an impartial, depoliticized, and incorruptible bureaucracy reduces the risk of interstate conflict.

Yet, robust bureaucratic quality also requires links between state bureaucrats and societal actors, notably business. For example, Block (1987) draws on the experience of high-income countries to show that when business interests acquire too much influence over the state administration, state policies will be least successful in solving societal problems. In a development context, the economic trajectory of the East Asian "tiger" countries highlights the importance of well-targeted industrial policy interventions aimed at addressing key impediments to catching up with high-income countries (Amsden 1989; Wade 1990; Evans 1998; Kohli 2004). These interventions are most impactful under conditions of "embedded autonomy" of the state bureaucracy; that is, a state-society arrangement in which bureaucrats enjoy autonomy from, but also close ties to, business elites to devise and implement successful policies (Evans 1995). In other words, embeddedness requires that bureaucrats have a close eye on the needs of businesses to identify the appropriate development policies. Indeed, "only a well-trained bureaucracy will be able to manage the strategic collaboration . . . between the private sector and the government with the aim of learning where the most important bottlenecks are" (Rodrik 2014, p. 485). Effective delivery of public services is endangered, however, if bureaucrats fall prey to particularistic interests (Rothstein and Teorell 2012).

\section{World Systems, Dependency, and State Capacity} in the Developing World

While scholars have long discussed domestic forces underpinning state capacity (e.g., Gellner 1983; Gorski 1993; Geddes 1994), in this article we focus on its international determinants. To be sure, we are not the first to draw attention to global factors. For example, Tilly (1990) shows that the threat of war increased pressures for states to build centralized administrations. However, we are interested in those determinants of administrative struc- 
tures that denote agency by some global actors. In this regard, the IMF as an "agent of neoliberalism" (Babb and Kentikelenis 2018; also Hironaka 2014, pp. 77-103) represents an international force that exerts direct policy pressure toward unleashing market forces in developing countries (Wade 2001, 2002).

One body of scholarship in global and transnational sociology has emphasized mimetic and normative isomorphic processes that result in the gradual spread of policy scripts circulating transnationally, as states adopt them to suit their purposes (Meyer et al. 1997; Schofer and Hironaka 2005; Drori and Meyer 2006; Frank, Longhofer, and Schofer 2007; Chorev 2012; Schofer et al. 2012; Boyle, Kim, and Longhofer 2015; Longhofer et al. 2016; Broome, Homolar, and Kranke 2017). In relation to the IMF, mimetic isomorphism occurs when states emulate the behavior of more successful countries that have adopted the organization's policy advice (Henisz, Zelner, and Guillén 2005; Dobbin, Simmons, and Garrett 2007; Pinheiro et al. 2015), and normative isomorphism describes how IMF staff interact with local officials via technical assistance to bring about new state norms (Chwieroth 2007; Broome and Seabrooke 2015).

In contrast to these soft and slow isomorphic processes, we deploy insights from dependency and world systems theories to understand how IMF lending programs affect state capacity. ${ }^{2}$ These theories emphasize that countries interact in a hierarchical global economic architecture in which core or advanced nations reproduce conditions of underdevelopment for peripheral or developing nations (Wallerstein 1974, 1979; Amin 1976). The earliest studies in this tradition argued that the economic penetration of developing countries by advanced countries - in the form of exploitative trade and investments in natural resources - stunted economic development in the former through transfers in surplus to the latter (Baran 1957; Frank 1967). The consequences of dependency for state capacity remained generally undertheorized, but the implication was that underdevelopment would persist. As Wallerstein (1979, p. 20) explained, strong "state machineries in core areas has as its direct counterpart the decline of the state machineries in peripheral areas." Indeed, since potentially taxable surpluses shifted to advanced nations through exploitative relationships, peripheral states were consigned to perennially limited public revenues to invest in building up capable bureaucracies (Kentor 1981).

\footnotetext{
${ }^{2}$ To be sure, dependency and world systems theories are not entirely equivalent; most notably, the former argued that the capitalist world economy had a bimodal core-periphery structure, while the latter added appreciation for the "semi-periphery" (Karataşl1 2017). However, in relation to state capacity, both theories reach similar conclusions: weak state capacity prevails (Wallerstein 1979).
} 
Importantly, one strand of world systems thinking articulated state capacity as an essential component for peripheral states to improve their position among peripheral countries; that is, to achieve so-called dependent development (Evans 1979). Rather than a paragon of Weberianness (as defined above), the dependent-development state is primarily the instrument of the national-industrialist capitalist class allied with international capital (Evans 1979). By implication, such states are proficient at advancing the interests of ruling economic and political elites, often in the context of authoritarianism. Yet, they lack the bureaucratic apparatus necessary to effectively deliver public goods. For example, over the 1960s and 1970s, the captured bureaucracy of Kenya under President Jomo Kenyatta delivered concentrated benefits to political and economic elites of the president's own ethnic group (the Kikuyu) but failed to implement policies that would improve the longrun developmental trajectory of the country or the well-being of nonaligned ethnic groups (Leys 1975; Stubbs 2015).

While initial studies on trade exports and investments in raw material production or agriculture focused on relationships of colonial dominance, scholars soon emphasized new forms of dependency consolidated in the postwar period. They argued that foreign aid constituted an extension of the relationship of dependency that served to preserve or widen economic disparities between core and peripheral nations (Dos Santos 1970; Hayter 1971; see also Moyo 2009). In this context, donor states provide aid to increase the likelihood that governments of the periphery will tolerate the continuation of outflows of private profits and interest on past debts (Hayter 1971). Such aid may support governments by providing a short-term solution to economic difficulties, but in the long term it perpetuates dependence on continued foreign aid flows (Hayter 1971). A separate strand of literature also highlighted how aid may undermine state capacity: countries with greater foreign aid revenue are less reliant on tax revenues drawn from citizens and thus face less domestic pressure to maintain popular legitimacy through investment in effective public institutions (Bräutigam and Knack 2004; Moss, Pettersson, and Van de Walle 2006).

More recent perspectives document how international financial institutions (IFIs) - the IMF, the World Bank, and regional development banks - deepen core-periphery dependency relations (Bradshaw and Huang 1991; Shandra et al. 2004; Harper and Snowden 2017). These studies posit that IFIs inhibit economic development by siphoning surplus from developing countries in the form of debt and interest payments on loans. Further, the practice of conditionality gives creditors - the high-income countries controlling IFI operations - unparalleled leverage to alter the political economies of borrowing countries in the interests of the West (Stone 2002; Babb 2009). Most conspicuously, Western business and financial interests have benefited from securing contracts and expanding their access to developing countries implementing 
structural adjustment programs (Wedel 1998; Gould 2003; Sassen 2014). This evidence is in line with the expectations of world systems theory: the conditionalities of the IMF and development banks entrench developing countries within the periphery of the global economic architecture. However, scholars have yet to macrocomparatively examine the specific impact of international organizations - like the IMF — on state capacity, even though qualitative case studies find evidence of a negative effect (Ban 2016).

In short, according to world systems and dependency theories, weak states occupy peripheral positions in the world economic order and are kept compliant through their dependence on foreign investment, aid, and loans from IFIs. In this context, these institutions affirm the power inequities inherent in globalization (Halliday and Carruthers 2009). The empirical challenge, then, is to identify how world system pressures affect state capacity in the developing world, and - to this end - we focus on the case of the activities of the IMF, widely considered "the world's most powerful agen[t] of economic reform" (Halliday and Carruthers 2007, p. 1137). In other words, this organization serves as a "strategic research site" (Merton 1987), offering an analytical lens for empirical scrutiny into the organizational apparatus of the world system and its impact on state capacity.

\section{IMF CONDITIONALITY AND BUREAUCRATIC QUALITY}

To what extent and how does IMF conditionality affect bureaucratic quality, a key element of state capacity? The substantive content of conditionality reflects the belief in neoclassical economics - an intellectual tradition firmly located in core capitalist nations (Fourcade-Gourinchas and Babb 2002) - that states should perform a minimal role in the economy (Callaghy 1989, p. 116). According to this line of thinking, government interventions in the economy, especially through industrial policy, crowd out the private sector and spur rent seeking and inefficient allocation of resources (e.g., Krueger 1974). Having embraced such ideas during training at prestigious economics departments (like the University of Chicago) and emboldened by the rise to power of free-market ideologues (like Ronald Reagan and Margaret Thatcher), IMF staff put antistate economic theories into policy practice from the 1980s onward (Babb 2009; Nelson 2014; Kentikelenis and Seabrooke 2017). Structural adjustment programs rolling out "Washington consensus" policies of privatization, liberalization, and deregulation became ubiquitous across the developing world (Williamson 1990; Summers and Pritchett 1993; Babb 2009). As world systems perspectives would predict, lending programs under IMF auspices generally failed to promote economic growth (Dreher 2006), and their socioeconomic consequences were deleterious (Babb 2005; Sassen 2014; Kentikelenis 2017, 2018; Stubbs and Kentikelenis 2017; Daoud and Reinsberg 2018; Reinsberg et al. 2019). 
Examining the causes of poor performance, political economists have noted the paradox that structural adjustment programs assume states' capability to implement complex economic and administrative policies and simultaneously stipulate reforms that hollow out the state, most notably by defunding or restructuring the bureaucracy (Callaghy 1989; Haggard and Kaufman 1989; Biersteker 1990; Haggard and Kaufman 1992, p. 25; Waterbury 1992). Eventually, this reality caught up with IMF staff, who-from the 1990s - started to promote the "good governance" agenda, itself a set of Western norms about how states should be organized (Kiely 1998). These efforts centered on reducing corruption by limiting the scope of bureaucratic authorizations, introducing tax reforms, increasing fiscal transparency, and removing price subsidies on government services (Mitra et al. 2016). Critics of this approach have long noted that, while many elements of this policy agenda are desirable, they are neither necessary nor sufficient criteria for spurring development (Kiely 1998). The tailoring, sequencing, and pacing of reforms is of utmost importance but rarely given appropriate treatment in blanket one-size-fits-all good governance prescriptions (Grindle 2004). Indeed, countries that have managed to escape underdevelopment built up bureaucratic capacities despite not meeting most tenets of this policy agenda (Wade 1990).

We build on - but also depart from - world systems accounts of the role of powerful international organizations. After all, these organizations are developed to solve global coordination problems, and membership carries some privileges and opportunities for countries that join (Barnett and Finnemore 2004). For example, a key mandate of the IMF is to help countries achieve balance-of-payments stability, a factor contributing to economic development and not ipso facto dependency inducing. What matters is how this mandate is put to practice. Our starting premise is that not all IMF programs are alike and that we need to consider the content of specific conditions. Following previous studies and the IMF's own classificatory schema, we distinguish between "structural conditions" and "stabilization conditions" (e.g., Vreeland 2007; Dreher 2009; Woo 2013). This distinction is useful because it allows us to untangle the bureaucratic quality effect of quantitative reductions in state activity in the economy from the effect of qualitative changes in the ways that states govern societies.

\section{Structural Conditions and Bureaucratic Quality}

Since the mid-1980s, the IMF advocated structural conditions to tackle the purported root causes of economic weakness (Nowzad 1981; Khan and Knight 1983; Polak 1991). Structural conditions have attracted criticism because they impinge on the sovereignty of borrowers, while at the same time failing to demonstrate effectiveness in resolving economic crises (Easterly 2005). We add to this criticism that structural conditions undermine bu- 
reaucratic quality through their impact on the behavior of state bureaucrats and private businesses.

Structural conditions lower the ability of the state to attract or retain qualified personnel. These conditions cut deeply into public sector entitlements, including working conditions, social security, average pay, and additional benefits. For example, Armenia's 1995 IMF program required the government to "finalize a plan to . . eliminat[e] or merge ministries" (IMF 1995, p. 16). In 1996, Georgia was asked to "reduce the number of ministries and committees" (IMF 1996, p. 25). The IMF also pushed for wage cuts and greater wage dispersion. For example, in Bulgaria, the government was required to "submit ... amendments to the Labor Code with provisions making hiring, firing, and working hours more flexible" (IMF 2000, p. 68). In addition, structural conditions ask countries to cede ownership of state-owned enterprises to private actors. The IMF argues that these measures are necessary to improve the business climate, foster job creation, and support growth over the medium term (IMF 2014), identifying the public sector as the major cause of fiscal deficits and sluggish performance (Waterbury 1992, p. 183). But these measures carry important downsides for the bureaucracy, as job insecurity and reduced pay may result in resignations, early retirements, or reduced willingness to deliver public services impartially.

From the perspective of business actors, structural conditions seek to remove privileges (i.e., rent extraction) in selected sectors of the economy. For example, in its program with Bulgaria, the IMF mandated issuance of a decree that eliminated tariff quotas and exemptions. The same agreement mandated lower import tariffs for a range of goods and a reduction in the dispersion of tariff rates. Other conditions seek to eliminate state subsidies, price guarantees, and regulatory protections. From the perspective of the IMF, the rationale for these measures "stems from the purposes of the IMF and the importance of open trade regimes for sustainable growth, durable macroeconomic stabilization, and balance of payments viability" (IMF 2001b). However, threatened by the removal of protection, businesses will increase their efforts to lobby state bureaucrats to prevent the envisaged policy changes (Haggard and Kaufman 1989, p. 223). As a consequence of structural conditions, business actors may thus paralyze the state administration with requests to protect their privilege.

\section{Stabilization Conditions and Bureaucratic Quality}

The IMF considers economic crises to primarily be the result of excessive demand; consequently, its policy conditions seek to reduce aggregate demand (Polak 1991). For this purpose, the IMF mandates stabilization conditions on macroeconomic variables such as external debt, the fiscal balance, and inflation rates. Stabilization conditions specify broad targets on these mac- 
roeconomic variables with a view to achieve balance-of-payments stabilization in the short term.

To be sure, adjustment toward stringent stabilization targets can worsen economic crises (Przeworski and Vreeland 2000; Dreher 2006; Dreher and Walter 2010) and impose high social costs (Babb 2005; Kentikelenis 2017; Stubbs et al. 2017; Stubbs and Kentikelenis 2018). However, with respect to bureaucratic quality, stabilization conditions are neutral. This is because these conditions do not necessarily change the ways in which the state carries out its functions (Tanzi 1998). For example, almost all IMF programs require ceilings on government debt (Kentikelenis, Stubbs, and King 2016), as excessively high debt-to-GDP ratios increase borrowing costs and the likelihood of economic shocks. But there are several ways in which governments can limit their indebtedness: they may renegotiate the terms of existing debt contracts to ease debt service, reduce government subsidies, and boost tax collection; they may also take measures to promote economic growth, which reduces the debt-to-GDP ratio.

In short, stabilization conditions do not oblige governments to enact specific reforms but leave them with some discretion in how to achieve economic policy objectives. Governments will use this discretion to protect the state-society relationships that are vital to policy implementation. More specifically, governments will avoid alienating business interests and imposing burdens on the public sector unless explicitly forced to do so by respective structural conditions, as these interest groups are well-organized lobbies whose cooperation is required for policy implementation (Haggard and Kaufman 1992, p. 25; Caraway, Rickard, and Anner 2012). Thus, unlike structural conditions, stabilization conditions allow governments to circumvent difficult reforms that drain their implementing capacity. By leaving unaffected the ways in which states govern their relationships with important societal actors, stabilization conditions do not have the same negative impact on bureaucratic quality as structural conditions do.

\section{DATA AND METHODS}

Our initial data set comprises 141 developing countries observed from 1985 to $2014 .{ }^{3}$ We collapse all information into three-year periods. ${ }^{4}$ At most 11 periods are available per country. Arranging the data in three-year periods has two advantages. First, our substantive interest is in how IMF programs affect state capacity over the medium term. State capacity is an inherently

\footnotetext{
${ }^{3}$ We exclude high-income countries because they already have high bureaucratic quality in the period under study and almost no IMF programs, which would unduly raise the strength of our results.

${ }^{4}$ Our results are robust to averaging over two-year periods.
} 
slow-moving variable, so a focus on medium-term effects is justified because building capable states is almost impossible in the short run. Second, short-term measurement of state capacity is plagued with subjectivity bias, which implies that measures may react to events unrelated to what they are supposed to measure (Stubbs, King, and Stuckler 2014). Averaging observations over several years filters out noise due to perception bias; it also enhances the statistical properties of variables with discrete measurement levels (Dreher and Siemers 2009).

\section{Research Design \\ Dependent Variables}

State capacity is operationalized as BurEAucratic QuALITY, measured using the corresponding perception-based indicator from the International Country Risk Guide (ICRG). It scores high in "countries where the bureaucracy has the strength and expertise to govern without drastic changes in policy or interruptions in government services. In these low-risk countries, the bureaucracy tends to be somewhat autonomous from political pressure and to have an established mechanism for recruitment and training" (PRS Group 2015). ${ }^{5}$ The ICRG indicator on bureaucratic quality is widely used in the literature on state capacity (e.g., Van Rijckeghem and Weder 2001; Bäck and Hadenius 2008; Broich et al. 2015). To ease interpretation, we rescale the variable to range from 0 to 100 .

To check the validity of our outcome measure, we correlated the ICRG indicator with two widely used alternative cross-sectional measures of bureaucratic quality (see the online appendix). First, the ICRG measure is highly correlated with the Weberianness index and specifically its subcomponents on merit-based recruitment, competitive salaries, and bureaucratic quality (Evans and Rauch 1999). Second, the ICRG measure is strongly correlated with professionalism and impartiality of public administration, as measured by the Quality of Government Institute (Dahlström et al. 2015). Furthermore, following the methods proposed by Kurtz and Schrank (2007), we conduct auxiliary regressions to verify that the ICRG measure is not biased by perceived changes in bureaucratic quality, proxied by contemporaneous economic growth (see the online appendix). Using these empirical tests, we argue that the ICRG indicator closely captures the notion of bureaucratic quality.

In addition to using the ICRG measure, we examine an experience-based measure of bureaucratic quality that does not suffer from potential perception

${ }^{5}$ The codebook does not provide information as to how bureaucratic quality is being assessed but notes that assessments are made on the basis of subjective analysis of the available information. 
bias: the percentage of firms experiencing acts of bribery by public officials, available from the Business Environment and Enterprise Performance Survey (BEEPS; European Bank for Reconstruction and Development and World Bank 2016). While freedom from corruption is not tantamount to bureaucratic quality, a public administration that is relatively free of corruption is likely to be more capable than one that is mired by corruption (Rothstein and Teorell 2012). Indeed, empirical studies often rely on corruption as a proxy for administrative quality (Adserà, Boix, and Payne 2003; Bäck and Hadenius 2008; Charron and Lapuente 2010). We thus consider the BEEPS measure to be an appropriate alternative to the ICRG measure.

\section{Independent Variables}

As discussed earlier, our expectation is that not all parts of an IMF program affect bureaucratic quality. Different program elements - such as loan resources, loan conditions, and technical advice-may have different effects. Allowing for such effect heterogeneity, we employ several measures.

In regressions that seek to establish the total effect of IMF programs, we use a binary variable indicating the presence of an IMF PROGRAM in the relevant period. This variable captures the overall effect of IMF involvement (e.g., Vreeland 2003; Atoyan and Conway 2006; Nooruddin and Simmons 2006). We subsequently conduct regressions among observations with IMF programs that include the number of Structural Conditions and Stabilization Conditions in these programs. ${ }^{6}$

For robustness tests, we use additional indicators, such as the total number of conditions (Dreher and Vaubel 2004; Copelovitch 2010). Referred to as ALL Conditions in regression outputs, the total number of conditions captures the overall depth of conditionality. In addition, we test separately for the impact of conditions on the Public Sector, Privatization of State-Owned EnterPrises, and Price Deregulation.

We only count binding conditions in each category, which include socalled prior actions and performance criteria (Dreher 2009; Copelovitch 2010; Woo 2013; Stubbs et al. 2017). This choice is appropriate because binding conditions directly determine scheduled disbursements of loans: failure to implement them can lead to program suspensions. In contrast, nonbinding conditions serve as markers for broader progress assessment, and nonimplementation does not automatically suspend loan payments (IMF 2001a).

\footnotetext{
${ }^{6}$ It is useful to include both conditions in one regression to untangle the effects of both types of conditionality. Woo (2013) includes only the number of structural conditions along with a program dummy, which is problematic because the estimate on structural conditions may also pick up some effects of stabilization conditions to the degree that both types of conditions are correlated.
} 
IMF variables are drawn from a newly constructed database on IMF conditionality from 1985 to 2014 (Kentikelenis et al. 2016). All above variables are lagged by one period to allow for some delay in the realization of effects.

\section{Control Variables}

We rely on a set of control variables drawn from the literature on state capacity. Most studies focus on the macrohistorical determinants of state capacity, which include legal origin, geography, and ethnolinguistic fractionalization (e.g., Alonso and Garcimartín 2013; Savoia and Sen 2015). Our inclusion of country fixed effects obviates the need to control for these time-invariant measures; subsequently, we thus focus on time-varying correlates of bureaucratic quality (Bräutigam and Knack 2004; Bäck and Hadenius 2008; Charron and Lapuente 2010). Bureaucratic quality is driven by a range of socioeconomic factors. First, we include the natural log of GDP PER CAPITA, given that wealthier states are better able to sustain capable bureaucracies (e.g., Bäck and Hadenius 2008). We also include the level of democracy measured by the PoLITY IV IndEX (Marshall, Gurr, and Jaggers 2015). Citizens in democracies hold government more accountable and are able to express demands for public goods, which should increase incentives to invest into a capable bureaucracy (Bäck and Hadenius 2008; Charron and Lapuente 2010; Fortin-Rittberger 2014). Empirical studies also show a positive effect of democracy on governance quality, measured by the control of corruption (Montinola and Jackman 2002), bureaucratic quality (Bäck and Hadenius 2008), and various indexes of governance (Adserà et al. 2003; Charron and Lapuente 2010). In addition, we measure the incidence of CIVIL WAR (Gleditsch et al. 2002), which negatively affects the extractive capacity of the state and thereby reduces its capacity (Centeno 2002; Besley and Persson 2008) and is in contrast to external war that offers incentives to invest in state capacity (Tilly 1990; Besley and Persson 2008; Lektzian and Prins 2008). The above control variables are used in most studies on state capacity, and therefore we consider them a minimal set.

In robustness checks, we expand the set of control variables to include variables on integration into the world economy and access to nontax resources. In particular, TRADE OPENNESS may indicate the entrenchment of exploitative trade relationships with core nations that diminish resources in peripheral nations to build state capacity (Kentor 1981); alternatively, it may increase pressures for redistribution and hence the need for a more sophisticated bureaucratic apparatus (Bäck and Hadenius 2008). We transform this variable using the natural logarithm to normalize its distribution. Economists have also noted the potential benefits of foreign direct investment (FDI) for state institutions (Bengoa and Sanchez-Robles 2003; Alfaro, 
Kalemli-Özcan, and Sayek 2009), whereas dependency theorists view it as an additional transfer in surplus to the core (Baran 1957; Frank 1967); we therefore include the natural log of FDI InFLOws as a percentage of GDP. Aid dependence - measured by Official Development Assistance (ODA) per capita - could both enhance and diminish bureaucratic quality. While it provides resources that can be used to build administrative capacity (Jones and Tarp 2016), it also represents nontax revenue and hence might reduce accountability (Moss et al. 2006; Djankov, Montalvo, and Reynal-Querol 2008). Finally, we include the natural log of OIL Production per capita as another important source of nontax revenue (Humphreys 2005; Thies 2010; Ross 2013). ${ }^{7}$ The online appendix presents descriptive statistics (table B1) and detailed variable definitions (table B2).

In addition to these variables, we always include a lagged dependent variable, country fixed effects, and period fixed effects. Inclusion of the lagged dependent variable reflects the fact that bureaucratic quality moves rather slowly, while also addressing concerns about serial correlation (Keele and Kelly 2005). Country fixed effects absorb all unobserved time-invariant heterogeneity, and period fixed effects capture period-specific factors that affect all countries equally with respect to bureaucratic quality. Finally, we also checked for potential nonstationarity in the dependent variable (table B7) using the augmented Dickey-Fuller test, which rejects the null hypothesis that panels contain a unit root $(P<.001)$.

\section{Methods}

Our analysis proceeds in two steps. First, we estimate the total effect of IMF programs on bureaucratic quality by comparing the evolution of bureaucratic quality for countries that underwent IMF programs and those that did not. Second, for all countries under IMF programs, we compare countries with specific conditions to those without, thus estimating the effect of conditionality (among panel observations with IMF programs). ${ }^{8}$ This approach enables us to isolate the kinds of conditions with the strongest impact on bureaucratic quality.

This approach involves two challenges. The first one is the well-known sample selection bias, which arises because borrowing countries are inherently different from nonborrowing countries, and these differences may be systematically related to bureaucratic quality. The conventional approach to

\footnotetext{
${ }^{7}$ Unless otherwise stated, control variables are drawn from the Quality of Government Institute database (Teorell et al. 2016).

${ }^{8}$ We conduct the instrumental variables analysis using multiequation maximum-likelihood estimation with correlated errors, available through Stata module cmp (Roodman 2011).
} 
address nonrandom selection is a Heckman model (see the online appendix). The main idea is to explicitly model the selection into IMF programs and then use the so-called inverse Mills ratio as an additional predictor in the bureaucratic quality equation. We employ a standard set of variables from previous literature to explain selection of countries into IMF programs. To enhance the reliability of the estimation, at least one of those variables should serve as an "exclusion restriction"- - a variable that explains program participation but does not affect bureaucratic quality except through its impact on program participation. Following previous literature, we argue that the alignment of voting patterns between the borrowing country and the Group of Seven countries in the United Nations General Assembly (UNGA) fulfills this criterion because political allies of big powers receive favorable treatment in the IFIs (Thacker 1999; Barro and Lee 2005; Dreher, Sturm, and Vreeland 2009). At the same time, the voting behavior of IMF borrowers is plausibly unrelated to bureaucratic quality. We therefore include the variable UNGA Vote Alignment (Bailey, Strezhnev, and Voeten 2015). In addition, we include the number of Countries under Programs, since program participation is affected by the extent to which the IMF has resources available; this in turn depends on the current number of program countries (Vreeland 2003, p. 88). Moreover, past involvement of a country in an IMF program reliably predicts current participation (Easterly 2005). We thus include PASt PRogram, a dummy variable indicating whether a country had a program before. These three variables - along with regional effects and time period dummies - explain a significant proportion of IMF programs and therefore constitute our baseline variables in the selection equation. In an extended specification presented in the online appendix, we add macroeconomic fundamentals, including foreign reserves, debt service, current account balance, as well as political factors, notably the incidence of national elections. In preview of our findings, we find that different specifications for the selection model do not affect our main results.

An additional challenge - not relevant for previous research that only used program dummies to identify the effect of IMF programs - is potential endogeneity of conditions. For example, countries may be more likely to obtain certain types of policy conditions from the IMF precisely because their bureaucratic quality is weak to begin with. In this case, our estimates would reflect this selection process rather than the genuine impact of conditions on our outcome of interest. To address this challenge, we use an instrument for IMF conditionality. In our case, a valid instrument is a variable that predicts the number of conditions (relevance criterion) but affects bureaucratic quality only through its impact on conditionality (exclusion criterion). Instruments are hard to find, but we are able to draw on an instrumentation strategy that has been popularized mainly in aid effectiveness research (e.g., Bun and Harrison 2014; Nunn and Qian 2014; Lang 2016). For each type of condition, we 
construct a compound instrument based on the interaction of the withincountry average of these conditions and the period-specific budget constraint of the IMF as measured by the number of Countries under Programs. This instrument is relevant because if the IMF needs to assist more countries, its budget constraint becomes binding, and it will require more conditions to safeguard repayment (Vreeland 2003; Dreher and Vaubel 2004; Lang 2016). The instrument is valid, too, because even if there were endogeneity between the time-variant budget constraint and bureaucratic quality, the exclusion restriction would only be violated if the unobserved variables driving this relation were correlated with the country-specific average of conditionality (see, e.g., Bun and Harrison 2014; Lang 2016; Stubbs et al. 2018). In all regressions that involve conditionality, we control for the nonselection hazard, in order to remove potential bias due to an unrepresentative sample. ${ }^{9}$

\section{RESULTS}

\section{Total Effect of IMF Programs}

We utilize multivariate analysis using data aggregated into three-year periods. Table 1 reveals no significant relationship between IMF programs and bureaucratic quality. This finding holds for alternative sets of control variables. Model 1 includes no control variables except for the lagged dependent variable (called $\mathrm{X} 0$ ) in the outcome equation and minimal controls in the selection equation (Z1). Model 2 adds the most commonly used control variables to the outcome stage - income per capita, democracy, civil war, and economic growth (X1). Model 3 includes additional variables related to demographics, economic integration, and resource endowments (X2). The last two models extend the set of variables in the selection equation to include macroeconomic variables from the World Development Indicators (World Bank 2015) — currency reserves, debt service, and external balance — and indicators for national elections from the Database of Political Institutions (Beck et al. 2001) to capture political motivations for requesting IMF support (Z2). Inclusion of these variables reduces the number of observations; therefore, a trade-off exists between model fit versus model parsimony and estimation efficiency.

In general, we find that coefficient estimates of control variables in the outcome equation depend on the specification of the selection equation. Model 5 yields results consistent with theoretical expectations; for example, factors relating positively to bureaucratic quality include income per capita and FDI inflows, while civil war is negatively related.

\footnotetext{
${ }^{9}$ We are concerned that data are not missing at random, which could bias our results. As we show in the online appendix, this concern is unwarranted: missingness in the dependent variable is unrelated to IMF program status and a host of other control variables.
} 
TABLE 1

Total Effect of IMF Programs on Bureaucratic Quality

\begin{tabular}{|c|c|c|c|c|c|}
\hline & (1) & (2) & (3) & (4) & (5) \\
\hline IMF program & $\begin{array}{c}1.41 \\
(1.59)\end{array}$ & $\begin{array}{c}.45 \\
(1.62)\end{array}$ & $\begin{array}{l}-.06 \\
(1.75)\end{array}$ & $\begin{array}{c}-2.67 \\
(2.05)\end{array}$ & $\begin{array}{r}-1.79 \\
(2.12)\end{array}$ \\
\hline \multicolumn{6}{|l|}{ Lagged bureaucratic } \\
\hline quality ............ & $\begin{array}{l}.76 * * * \\
(.02)\end{array}$ & $\begin{array}{l}.76 * * * \\
(.02)\end{array}$ & $\begin{array}{l}.76 * * * \\
(.02)\end{array}$ & $\begin{array}{l}.75 * * * \\
(.02)\end{array}$ & $\begin{array}{l}.76^{* * * *} \\
(.02)\end{array}$ \\
\hline Log(GDP per capita) $\ldots$. & & $\begin{array}{l}4.97 * * * \\
(1.76)\end{array}$ & $\begin{array}{l}4.61 * * \\
(2.02)\end{array}$ & $\begin{array}{l}3.38 \\
(2.14)\end{array}$ & $\begin{array}{l}4.53^{*} \\
(2.59)\end{array}$ \\
\hline Polity IV index $\ldots \ldots \ldots$ & & $\begin{array}{l}.04 \\
(.10)\end{array}$ & $\begin{array}{c}-.07 \\
(.11)\end{array}$ & $\begin{array}{l}.05 \\
(.12)\end{array}$ & $\begin{array}{c}-.01 \\
(.13)\end{array}$ \\
\hline Civil war. . . . . . . . & & $\begin{array}{c}-2.43 \\
(1.83)\end{array}$ & $\begin{array}{c}-1.91 \\
(1.91)\end{array}$ & $\begin{array}{l}-6.65 * * * \\
(2.01)\end{array}$ & $\begin{array}{l}-4.91 * * \\
(2.08)\end{array}$ \\
\hline GDP growth $\ldots \ldots \ldots \ldots$ & & $\begin{array}{l}.10 \\
(.07)\end{array}$ & $\begin{array}{l}.09 \\
(.10)\end{array}$ & $\begin{array}{l}.15 \\
(.11)\end{array}$ & $\begin{array}{l}.11 \\
(.14)\end{array}$ \\
\hline $\log ($ dependency ratio) ... & & & $\begin{array}{c}1.99 \\
(4.66)\end{array}$ & & $\begin{array}{l}-.15 \\
(8.20)\end{array}$ \\
\hline Log(trade openness) . . . . & & & $\begin{array}{l}3.04^{* *} \\
(1.51)\end{array}$ & & $\begin{array}{l}-.80 \\
(2.00)\end{array}$ \\
\hline $\log (\mathrm{FDI}$ inflows $) \ldots \ldots$ & & & $\begin{array}{l}.76 \\
(.61)\end{array}$ & & $\begin{array}{l}1.62 * * \\
(.71)\end{array}$ \\
\hline Log(ODA per capita) $\ldots$. & & & $\begin{array}{l}.30 \\
(.49)\end{array}$ & & $\begin{array}{c}-.21 \\
(.53)\end{array}$ \\
\hline Log(oil per capita). . . . . & & & $\begin{array}{r}-1.14 \\
(.76)\end{array}$ & & $\begin{array}{r}-1.30 \\
(.82)\end{array}$ \\
\hline $\begin{array}{l}\text { Outcome equation } \\
\quad \text { controls } \ldots \ldots \ldots \ldots\end{array}$ & X0 & $\mathrm{X} 1$ & $\mathrm{X} 2$ & $\mathrm{X} 1$ & $\mathrm{X} 2$ \\
\hline $\begin{array}{l}\text { Selection equation } \\
\text { controls } \ldots \ldots \ldots \ldots\end{array}$ & $\mathrm{Z} 1$ & $\mathrm{Z} 1$ & $\mathrm{Z} 1$ & $\mathrm{Z2}$ & $\mathrm{Z} 2$ \\
\hline Observations.......... & 718 & 633 & 595 & 467 & 449 \\
\hline$\chi^{2} \ldots \ldots \ldots \ldots \ldots$ & $5,630.41$ & $5,333.58$ & $5,083.51$ & $3,866.86$ & $3,789.56$ \\
\hline
\end{tabular}

Note.-Sample includes all observations arranged in three-year periods. The dependent variable is Bureaucratic Quality (0-100). Standard errors clustered on countries shown in parentheses.

$* P<.10$.

** $P<.05$.

$* * * P<.01$

\section{The Effects of IMF Conditionality}

Following our theoretical discussion, we explore whether structural conditions are harmful for bureaucratic quality. By conditioning on observations with IMF programs, we essentially compare a program country under a specific conditionality profile to the same country under a different conditionality profile. Inclusion of an inverse Mills ratio addresses potential selection bias from only considering countries under IMF programs.

Table 2 presents regression results of bureaucratic quality on two key types of IMF conditions. Consistent with theoretical expectations, we find that structural conditions reduce bureaucratic quality; stabilization condi- 
tions do not have a significant impact. Note that these estimates can be interpreted causally as a result of instrumentation. Using model 5 to interpret effect magnitudes, we find that one structural condition reduces bureaucratic quality by, on average, 1.24 points on a $0-100$ scale $(P<.05)$, all else equal. For an increase by 1 standard deviation $(\mathrm{SD}=3.27)$, bureaucratic quality reduces by 4.04 points (one-fifth of its standard deviation). Given our dynamic model specification, a 1 standard deviation increase in the number of structural conditions thus exerts a cumulative impact of 18.4 points (almost 1 standard deviation of bureaucratic quality). ${ }^{10}$ Hence, the near-universal adoption of structural adjustment measures in the 1990s has substantive long-lasting effects.

The above results are credible for at least two reasons. First, our models include numerous control variables, which represent a more stringent test for our variables of interest. In particular, two-way fixed effects and a lagged dependent variable absorb a lot of variation. It is therefore not surprising that none of the control variables reach statistical significance. Second, our diagnostic statistics for the compound instruments are strong. The Kleibergen-Paap $F$-statistics are far above the conventional threshold of $10-$ a critical value below which the potential bias from weak instruments becomes too large to compensate for the original bias from not using any instruments at all (Staiger and Stock 1997). The $F$-statistics in our regressions imply that the bias from weak instruments is less than $5 \%$ of the endogeneity bias (Stock and Yogo 2005).

\section{Further Analyses}

We conduct additional analysis to ensure that our key findings are not driven by alternative explanations. In particular, we verify that structural conditions, rather than a more general burden of adjustment arising from a high number of program conditions, are responsible for the decline in bureaucratic quality. To discard this alternative interpretation, we examine the impact of All Conditions on bureaucratic quality, again using compound instrumentation to mitigate potential endogeneity. As shown in table 3, the number of conditions alone does not undermine bureaucratic quality. While the point estimate indeed is negative (mirroring the negative total effect of IMF programs earlier), it is not significant. It also is harder to find a strong instrument for the total number of conditions, most likely because there is less variation in the number of conditions than in the specific content of conditions.

${ }^{10}$ This is computed as follows: $\beta_{\mathrm{S}} /(1-\alpha)$, where $\alpha$ is the coefficient on the lagged dependent variable, and $\beta_{S}$ is the coefficient on structural conditions. 
In addition, our theory sheds some light on potential mechanisms through which conditionality affects bureaucratic quality, notably policy conditions on public sector employment, privatization of state-owned enterprises, and deregulation of prices. As discussed previously, public sector reforms mandated by the IMF may have detrimental effects on the ability of states to retain qualified personnel. As shown in table 3, we find significantly negative effects in three models (notably, the ones with the more credible set of control variables but with fewer observations included). Effect magnitudes are strong, given that each public sector condition is associated with a decline in bureaucratic quality by 4.49 points on average.

Conditions on the privatization of state-owned enterprises are thought to reduce bureaucratic quality by lowering the permissible range of instruments through which state administrations can influence market exchange. By removing states as stakeholders of businesses, privatization leads to a reduction in the flow of information between state bureaucrats and business representatives. Table 3 corroborates our expectations of a significantly negative effect of privatization conditions on bureaucratic quality. Regardless of model specification, coefficient estimates are substantively large and statistically significant $(P<.05)$; each privatization condition is associated with a decline in bureaucratic quality by up to 8.64 points.

Conditions on deregulating prices can reduce bureaucratic quality by removing the specific instruments necessary to devise smart industrial policies. Table 3 indeed shows a deleterious effect of price deregulation conditions on bureaucratic quality in four models. Substantively, each such condition reduces bureaucratic quality by up to 2.68 index points $(P<.05)$. Diagnostic statistics do not suggest weak-instrument bias.

The above results reveal the specific types of structural conditions that adversely affect bureaucratic quality, as echoed by previous qualitative research. For example, structural conditions have compromised the ability of some African states to adequately respond to the Ebola outbreak. While reforms to the remuneration of public health workers mandated by IMF conditions led to the emigration of qualified personnel, the decentralization of health care systems made it more difficult for state authorities to mobilize a coordinated response to the outbreak (Kentikelenis et al. 2015).

A remaining concern is the possibility that findings are driven merely by changes in perceptions about bureaucratic quality. Therefore, we verify that our argument holds using the BEEPS measure of the percentage of firms experiencing acts of bribery by public officials. In order to include country fixed effects, we discard all countries with less than two survey waves, which leaves us with 125 observations from 43 countries overall. As before, we first scrutinize the total impact of IMF programs before considering the two types of IMF conditions. Table 4 shows the results. Column 1 tests for the overall impact of IMF programs using country-level 


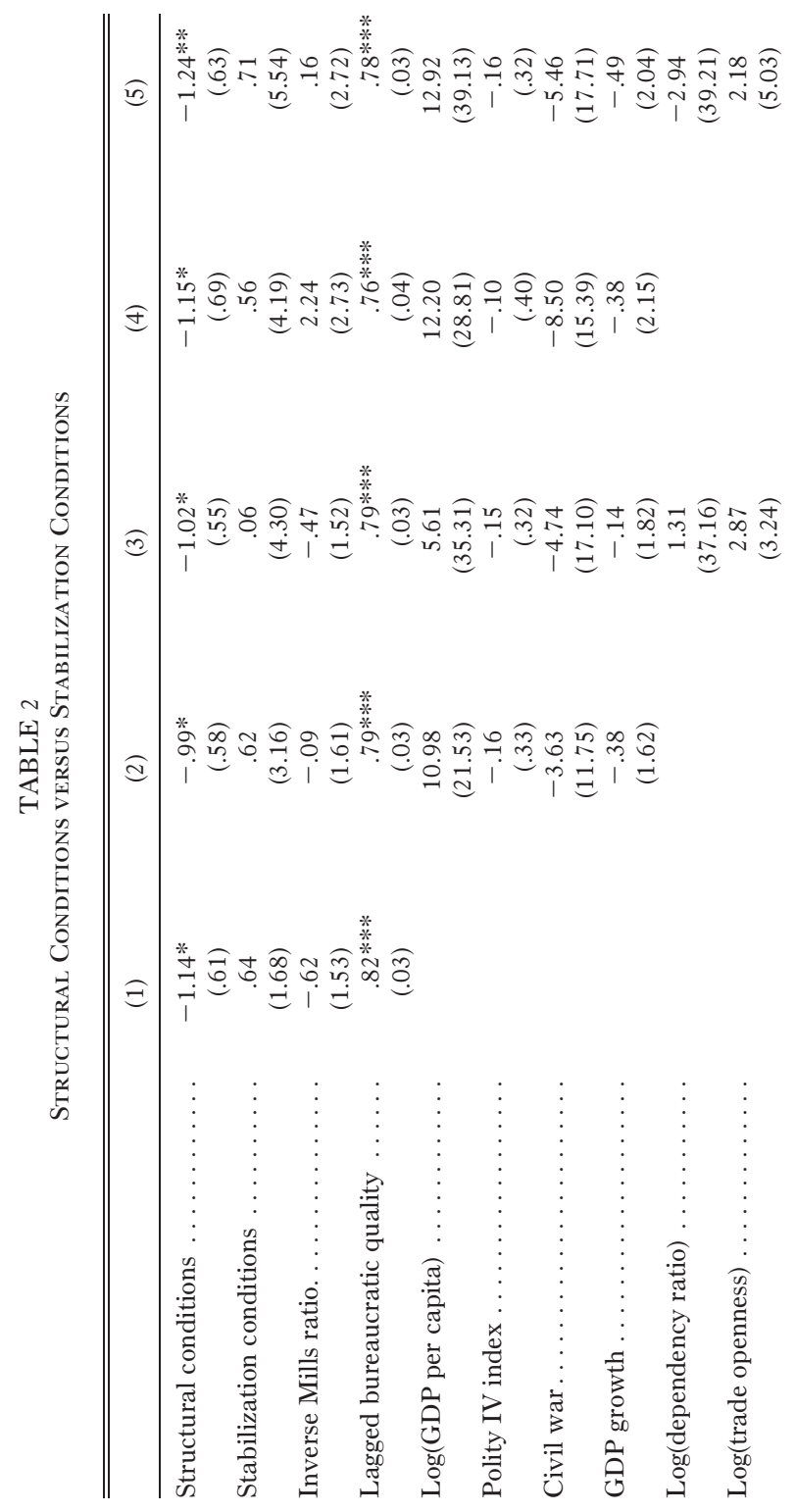




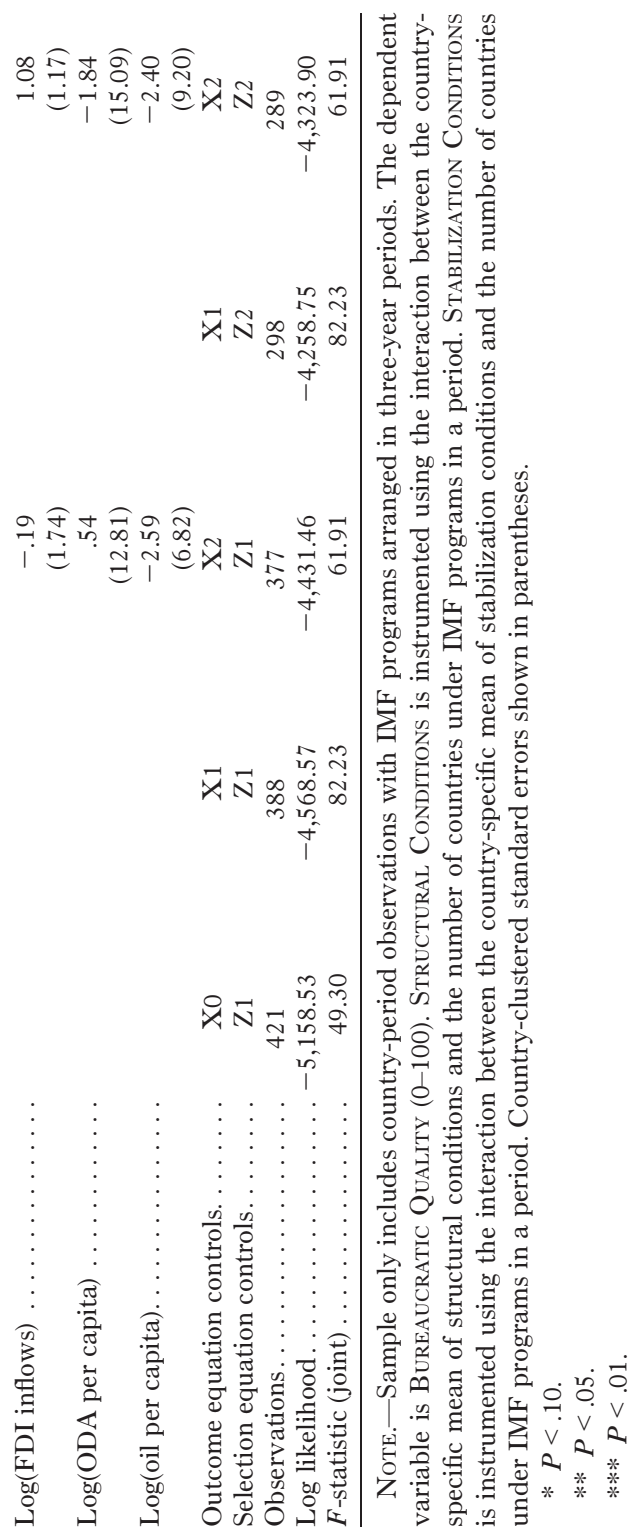




\section{American Journal of Sociology}

controls. When a country undergoes a program, its reported incidence of corruption increases by roughly $18 \%$. Column 2 suggests that structural conditions further increase corruption: each additional structural condition increases the percentage of firms experiencing acts of bribery by $2.7 \%$ $(P<.05)$. The effect of stabilization conditions remains insignificant. In the subsequent models, we add control variables available from the BEEPS survey related to firm characteristics. This improves model fit but turns the effect of IMF programs and the inverse Mills ratio insignificant. The negative effect of structural conditions becomes even stronger $(P<.05)$, while stabilization conditions tend to mitigate corruption in this model $(P<.10)$. Overall, the replicability of our results using an experience-based measure of bureaucratic quality increases our confidence in the main results.

TABLE 3

Further Regressions on IMF Conditionality and Bureaucratic Quality

\begin{tabular}{|c|c|c|c|c|c|}
\hline & (1) & (2) & (3) & (4) & (5) \\
\hline All conditions ...... & $\begin{array}{l}-.39 \\
(.43)\end{array}$ & $\begin{array}{l}-.50 \\
(.54)\end{array}$ & $\begin{array}{l}-.65 \\
(.64)\end{array}$ & $\begin{array}{l}-.71 \\
(.65)\end{array}$ & $\begin{array}{l}-.96 \\
(.76)\end{array}$ \\
\hline \multicolumn{6}{|l|}{ Public sector } \\
\hline conditions $\ldots \ldots \ldots$ & $\begin{array}{c}-2.45^{*} \\
(1.47)\end{array}$ & $\begin{array}{c}-1.77 \\
(1.47)\end{array}$ & $\begin{array}{c}-1.98 \\
(1.62)\end{array}$ & $\begin{array}{c}-3.83^{*} \\
(2.07)\end{array}$ & $\begin{array}{l}-4.49 * * \\
(2.15)\end{array}$ \\
\hline \multicolumn{6}{|l|}{ Privatization } \\
\hline conditions & $\begin{array}{l}-8.18^{* *} \\
(3.58)\end{array}$ & $\begin{array}{l}-7.52 * * \\
(3.48)\end{array}$ & $\begin{array}{l}-8.21 * * \\
(3.87)\end{array}$ & $\begin{array}{l}-7.82 * * \\
(3.77)\end{array}$ & $\begin{array}{l}-8.64 * * \\
(4.00)\end{array}$ \\
\hline \multicolumn{6}{|l|}{ Price deregulation } \\
\hline conditions $\ldots \ldots \ldots$ & $\begin{array}{l}-2.55 * * \\
(1.05)\end{array}$ & $\begin{array}{l}-2.42 * * \\
(1.06)\end{array}$ & $\begin{array}{l}-2.58 * * \\
(1.01)\end{array}$ & $\begin{array}{r}-2.30 \\
(1.46)\end{array}$ & $\begin{array}{l}-2.68 * * \\
(1.35)\end{array}$ \\
\hline $\begin{array}{l}\text { Outcome equation } \\
\text { controls } \ldots \ldots \ldots\end{array}$ & $\mathrm{X} 0$ & $\mathrm{X} 1$ & $\mathrm{X} 2$ & $\mathrm{X} 1$ & $\mathrm{X} 2$ \\
\hline $\begin{array}{l}\text { Selection equation } \\
\text { controls }\end{array}$ & $Z_{1}$ & $Z_{1}$ & $Z_{1}$ & $\mathrm{Z} 2$ & $\mathrm{Z2}$ \\
\hline Observations. . . . . . . & 421 & 388 & 377 & 298 & 289 \\
\hline Log likelihood. . . . . . & $-3,725.12$ & $-3,312.63$ & $-3,208.46$ & $-3,001.81$ & $-2,904.99$ \\
\hline$F$-statistic $\ldots \ldots \ldots$ & 7.70 & 4.63 & 3.99 & 4.63 & 3.99 \\
\hline
\end{tabular}

Note.-Each panel corresponds to a separate set of regressions in which we test for the effect of the respective condition. Samples only include country-period observations with IMF programs (while including an inverse Mills ratio for selection correction), arranged over three-year periods. The dependent variable is Bureaucratic Quality (0-100). The respective number of conditions is instrumented using the interaction between the country-specific mean of these conditions and the number of countries under IMF programs in a period. All control variables are included but suppressed for reasons of limited space. $F$-statistic shown is for "all conditions," while $F>25$ for all other conditions. Country-clustered standard errors shown in parentheses.

$$
\begin{aligned}
& * P<.10 . \\
& * * P<.05 . \\
& * * * P<.01 .
\end{aligned}
$$


Hollowing Out State Capacity

TABLE 4

INCIDENCE OF CORRUPTION AND IMF CONDITIONALITY

\begin{tabular}{|c|c|c|c|c|}
\hline & (1) & (2) & (3) & (4) \\
\hline IMF program & $\begin{array}{l}17.95 * \\
(9.51)\end{array}$ & $\begin{array}{l}18.40 * * \\
(8.90)\end{array}$ & $\begin{array}{c}7.82 \\
(9.26)\end{array}$ & $\begin{array}{l}8.17 \\
(7.82)\end{array}$ \\
\hline Structural conditions .... & & $\begin{array}{l}2.70 * * \\
(1.28)\end{array}$ & & $\begin{array}{l}3.97 * * \\
(1.77)\end{array}$ \\
\hline Stabilization conditions . . . & & $\begin{array}{r}-.79 \\
(.59)\end{array}$ & & $\begin{array}{c}-.90 * \\
(.50)\end{array}$ \\
\hline Inverse Mills ratio. . . . . . . & $\begin{array}{c}-10.22 * * \\
(4.65)\end{array}$ & $\begin{array}{c}-10.70 * * \\
(4.18)\end{array}$ & $\begin{array}{c}-5.44 \\
(4.22)\end{array}$ & $\begin{array}{c}-5.34 \\
(3.32)\end{array}$ \\
\hline Fixed effects $\ldots \ldots \ldots \ldots$ & Yes & Yes & Yes & Yes \\
\hline Country controls....... & Yes & Yes & Yes & Yes \\
\hline Firm controls . . . . . . . & No & No & Yes & Yes \\
\hline Within $R^{2} \ldots \ldots \ldots$ & .19 & .65 & .22 & .62 \\
\hline Observations.......... & 125 & 125 & 123 & 123 \\
\hline$F$-statistic (joint) $\ldots \ldots \ldots$ & $\ldots$ & 54.13 & $\ldots$ & 50.79 \\
\hline
\end{tabular}

Note.-Dependent variable is the percentage of firms in the BEEPS survey reporting at least one incident of corruption by public sector officials. Data are average over three-year periods. As the BEEPS data contain an insufficient number of repeated time observations for the compound instrument approach, we use internal instruments as a second-best alternative. In this approach, we predict the (lagged) number of conditions by their second lag, standard controls, and time dummies. The exclusion restriction requires that there is no independent impact of twice-lagged conditionality on the outcome other than through its effect on lagged conditionality. Robust country-clustered standard errors in parentheses.

$$
\begin{aligned}
& * P<.10 . \\
& * * P<.05 . \\
& * * * P<.01 .
\end{aligned}
$$

\section{Robustness Tests}

The online appendix includes the results of all estimating equations as well as further robustness tests. With respect to selection into IMF programs, we find that past programs, low reserves in months of imports, current account deficits, and executive elections are robust predictors of current programs. Coefficients on UNGA voting patterns are not always statistically significant but have the expected sign. With respect to the determinants of structural conditions, we find that low per capita income, absence of civil war, low growth, and small inflows of FDI are significant determinants.

We also used an alternative definition of our conditionality variables that deducts the number of conditions for which countries obtained a waiver during the course of the adjustment program (table B3). In exceptional circumstances, but also as a result of intervention of big powers on behalf of their geopolitical allies, the executive board can waive certain conditions in order to help countries pass the staff review on their loan program (Babb and Carruthers 2008, p. 20). Taking waivers into account does not substan- 
tively alter the results. Coefficient estimates on structural conditions remain negatively significant in most models, while stabilization conditions remain insignificant. Applying the waiver correction to issue area conditions, we find that labor conditions remain statistically significant in only two models, privatization conditions remain negatively significant throughout all specifications, and the four estimates on price deregulation previously found to be significant also remain significant. Effect magnitudes are comparable, and instrument diagnostics are strong.

Finally, we show that our results do not hinge on the assumption that countries have high levels of bureaucratic quality to begin with. To be sure, state-society arrangements - such as embedded autonomy - require a professionalized bureaucracy (Haggard and Kaufmann 1992, p. 20); hence, structural conditions will have the most detrimental impact where they undermine intact state-society arrangements (while having less impact where such arrangements do not exist in the first place). However, even weak states have some pockets of bureaucratic quality (McDonnell 2017, p. 483); therefore, bureaucratic quality can decline as a result of conditionality, even in low-capacity states. We conduct a series of regressions excluding the (purportedly) least capable states; our argument would be supported if our effects remained similar, while it would be refuted if effects were to subside without these weak states. We use three different indicators of weak capacity: fragile states (World Bank 2016), low-income countries (gross national income per capita below US\$1,025), and countries in the lowest decile of initial bureaucratic quality. Our main results are unaffected by these sample restrictions.

\section{DISCUSSION AND CONCLUSION}

This article examined the impact of structural adjustment programs on the bureaucratic quality of developing countries. These programs coerce governments of nations in the global periphery to adopt policy reforms that - explicitly or implicitly - favor the interests of core capitalist nations and are thus ideal sites to study world system pressures. We used a data set of up to 141 developing countries observed over three-year periods from 1985 to 2014 and deployed an appropriate econometric toolkit to find that structural conditions lead to lower bureaucratic quality. Further probing into the policy issues targeted by conditionality, we find that conditions on state-owned enterprise privatization, price deregulation, and - to a lesser extent-public sector employment flexibility have a significantly negative effect on bureaucratic quality. Our argument is further bolstered by converging results on two separate indicators of bureaucratic quality - a perception-based measure from ICRG and an experience-based measure from firm surveys. 
Before discussing broader implications of our findings, we note two limitations. First, our results are based primarily on a subjective measure of state capacity. To be sure, subjective measures are widely used in the relevant literature (Adserà et al. 2003; Bräutigam and Knack 2004; Broich et al. 2015). Among these indicators, the ICRG index is still the most widely available (covering the period from 1984 to 2014), and its values can be compared over time. Another advantage is that they seek to measure capacity rather than willingness to provide public goods. However, subjective measures are not uncontroversial, mainly due to perception biases (Kurtz and Schrank 2007; Stubbs et al. 2014). To mitigate this concern, we averaged all observations into three-year periods to smooth out unsystematic variation while also testing the validity of the ICRG measure in auxiliary multivariate tests. Furthermore, we replicated our findings using a more objective measure of bureaucratic quality based on experienced corruption of firms with government officials, reported to the BEEPS.

A second limitation pertains to the more general problem of identifying causal relationships. Because of our use of instrumental-variable estimation, the negative effect of structural conditions on bureaucratic quality has a causal interpretation, while the main competing interpretation - that countries with weak state capacity receive systematically different conditions - can be ruled out. But definitive answers to complex cause-and-effect questions are rarely possible to obtain using the nonexperimental research designs typical of the social sciences and deployed in this study (Morgan and Winship 2007). Econometric innovations have emerged to ameliorate some of these concerns, but for every strategy there are untestable assumptions, such as the perennial problem of instrument excludability, as well as the possibility - however remote - that factors correlate with each other by happenstance. While we employed the most rigorous econometric methods available (replete with checks for robustness of results), ultimately case studies that gather both quantitative and qualitative data on mechanisms at the national level of analysis on why particular countries adopt particular IMF programs would further strengthen confidence in our findings.

More broadly, our study builds a theoretical and empirical bridge between world systems theory and Weberian-inspired political sociology. World systems perspectives give a broad-brush account of the emergence and entrenchment of weak states in developing countries as a direct result of the enrichment of advanced economies; alternatively, Weberian-inspired political sociology provides rich macrohistorical narratives rooted primarily in domestic political processes, which emphasize professional bureaucracies as an essential precondition for the development of a capable state. We showed that the global economy is structured in a way that undermines state capacity in poor countries and elucidated a set of causal mechanisms by which this process operates. By identifying the features of IMF programs that undermine bureaucratic 
quality, we also demonstrated that state capacity is amenable to direct policy intervention within much shorter time frames than sociologists had previously assumed. Taken together, our study offers a conceptual and methodological toolkit that enables scholars to intersect domestic and world systems level analyses, as the practices of international organizations - of which the IMF is but one important case - entrench global power asymmetries.

Viewed in this light, future research can take on the task of developing nuanced, mechanism-driven explanations of how the world system operates under the contemporary political-economic institutional environment. This can include tracing additional global-national or global-subnational links that lock in underdevelopment and critically examining success cases of peripheral countries that have managed to carve out specific paths to development (Cardoso 2009). An additional avenue for research is to advance analyses of the structure of contemporary globalization based on class (e.g., Block 1978; Sklair 2001) or epistemic privilege (e.g., Seabrooke and Tsingou 2014; Ban, Seabrooke, and Freitas 2016; Seabrooke and Henriksen 2017). International organizations, via the establishment of global rules and norms, assert and reinforce privileges of a transnational capitalist elite, and sociologists have long held the methodological tools necessary to advance these debates in a rigorous fashion (e.g., Domhoff 1990; Etzion and Davis 2008; Mizruchi 2016).

Given that social scientists from diverse subdisciplines concur that state capacity is decisive for development and that bureaucratic quality is an essential component of state capacity, our findings will appear as a major concern for policy makers. While to date no study examines the disaggregated impact of IMF conditionality on economic growth, previous work has established a significantly negative effect of IMF programs per se (Dreher 2006). Our article thus provides a plausible microfoundation for this result: IMF conditionality serves to undermine the state capacity underlying successful development policies that trigger sustained growth. Moreover, state capacity seems only to become increasingly important as we witness how so-called failed states can destabilize their neighbors, or even high-income countries further afield, via large-scale refugee flows or by fomenting extremism that threatens global peace. Indeed, failed states have moved center stage in recent academic debates (Risse and Krasner 2014), while also conjuring nightmarish perceptions of unbridled chaos in popular media. As the antithesis of capable states, they lack the ability to protect their borders and implement policies that could appease their peoples. Ironically, these are also the very sites that the IMF and other international organizations will be most intimately involved with in the future, potentially replete with detailed policy prescriptions designed to shape political economies in the image of Western countries.

Beyond our concern with state capacity, our study offers important lessons for all international organizations to consider. Deploying a conceptual 
toolkit derived from world systems theory and Weberian-inspired political sociology, we now know which elements of IMF programs are counterproductive and misguided (i.e., structural conditions seeking to rapidly overhaul domestic institutional arrangements). The stage is thus set for analogous considerations to be made at other international organizations. That said, it is also the case that an important role remains for the IMF and other IFIs in assisting countries to overcome balance-of-payments problems. Fulfilling this role effectively will require fundamental reforms to these organizations. Thankfully, would-be reformers need not look far for inspiration. John Maynard Keynes's (1943, esp. pp. 3-18) initial proposals for the IMF acknowledged that deficits in some countries are mirror images of surpluses in others, and so economic adjustment should not only apply to low-income debtor countries but also to high-income creditor countries.

\section{REFERENCES}

Adserà, Alicia, Carles Boix, and Mark Payne. 2003. "Are You Being Served? Political Accountability and Quality of Government." Journal of Law, Economics, and Organization 19 (2): 445-90.

Alfaro, Laura, Sebnem Kalemli-Özcan, and Selin Sayek. 2009. "FDI, Productivity and Financial Development." World Economy 32 (1): 111-35.

Alonso, José A., and Carlos Garcimartín. 2013. "The Determinants of Institutional Quality: More on the Debate.” Journal of International Development 25 (2): 206-26.

Amin, Samir. 1976. Unequal Development: An Essay on the Social Formations of Peripheral Capitalism, translated by Brian Pearce. New York: Monthly Review.

Amsden, Alice H. 1989. Asia's Next Giant: South Korea and Late Industrialization. Oxford: Oxford University Press.

Anderson, Benedict. 1991. Imagined Communities: Reflections on the Origin and Spread of Nationalism. New York: Verso.

Atoyan, Ruben, and Patrick Conway. 2006. "Evaluating the Impact of IMF Programs: A Comparison of Matching and Instrumental-Variable Estimators." Review of International Organizations 1 (2): 99-124.

Babb, Sarah L. 2005. "The Social Consequences of Structural Adjustment: Recent Evidence and Current Debates.” Annual Review of Sociology 31:199-222.

. 2009. Behind the Development Banks: Washington Politics, World Poverty, and the Wealth of Nations. Chicago: University of Chicago Press.

Babb, Sarah L., and Bruce G. Carruthers. 2008. "Conditionality: Forms, Function, and History." Annual Review of Law and Social Sciences 4:13-29.

Babb, Sarah L., and Alexander E. Kentikelenis. 2018. "International Financial Institutions as Agents of Neoliberalism." Pp. 16-27 in The Sage Handbook of Neoliberalism, edited by Damien Cahill, Melinda Cooper, Martijn Konings, and David Primrose. Thousand Oaks, Calif.: Sage.

Bäck, Hanna, and Axel Hadenius. 2008. "Democracy and State Capacity: Exploring a J-Shaped Relationship." Governance 21 (1): 1-24.

Bailey, Michael A., Anton Strezhnev, and Eric Voeten. 2015. "Estimating Dynamic State Preferences from United Nations Voting Data." Journal of Conflict Resolution 61 (2): 430-56.

Ban, Cornel. 2016. Ruling Ideas: How Global Neoliberalism Goes Local. Oxford: Oxford University Press. 


\section{American Journal of Sociology}

Ban, Cornel, Leonard Seabrooke, and Sarah Freitas. 2016. "Grey Matter in Shadow Banking: International Organizations and Expert Strategies in Global Financial Governance." Review of International Political Economv 23 (6): 1001-33.

Baran, Paul. 1957. The Political Economy of Underdevelopment. New York: Monthly Review.

Barnett, Michael, and Martha Finnemore. 2004. Rules for the World: International Organizations in Global Politics. Ithaca, N.Y.: Cornell University Press.

Barro, Robert J., and Jong-Wha Lee. 2005. "IMF Programs: Who Is Chosen and What Are the Effects?" Journal of Monetarv Economics 52:1245-69.

Beck, Thorsten, George Clarke, Alberto Groff, Philip Keefer, and Patrick Walsh. 2001. "New Tools in Comparative Political Economy: The Database of Political Institutions." World Bank Economic Review 15 (1): 165-76.

Bengoa, Marta, and Blanca Sanchez-Robles. 2003. "Foreign Direct Investment, Economic Freedom and Growth: New Evidence from Latin America." European Journal of Political Economy 19 (3): 529-45.

Besley, Timothy, and Torsten Persson. 2008. "Wars and State Capacity." Journal of the European Economic Association 6 (2-3): 522-30.

Biersteker, Thomas J. 1990. "Reducing the Role of the State in the Economy: A Conceptual Exploration of IMF and World Bank Prescriptions." International Studies Quarterlv 34 (4): 477-92.

Block, Fred L. 1978. The Origins of International Economic Disorder. Berkeley and Los Angeles: University of California Press.

. 1987. Revising State Theory: Essays in Politics and Postindustrialism. Philadelphia: Temple University Press.

Boyle, Elizabeth H., Minzee Kim, and Wesley Longhofer. 2015. "Abortion Liberalization in World Society, 1960-2009." American Journal of Sociology 121 (3): 882-913.

Bradshaw, York W., and Jie Huang. 1991. "Intensifying Global Dependency: Foreign Debt, Structural Adjustment, and Third World Underdevelopment." Sociological Ouarterlv 32 (3): 321-42.

Bräutigam, Deborah A., and Stephen Knack. 2004. "Foreign Aid, Institutions, and Governance in Sub-Saharan Africa." Economic Development and Cultural Change 52 (2): 255-85.

Broich, Tobias, Adam Szirmai, and Kai Thomsson. 2015. "Precolonial Centralisation, Foreign Aid and Modern State Capacity in Africa." Working paper. United Nations University, Maastricht Economic and Social Research Institute on Innovation and Technology.

Broome, André, Alexandra Homolar, and Matthias Kranke. 2017. "Bad Science: International Organizations and the Indirect Power of Global Benchmarking." European Journal of International Relations 20 (4): 469-84.

Broome, André, and Leonard Seabrooke. 2015. "Shaping Policy Curves: Cognitive Authority in Transnational Capacity Building." Public Administration 93 (4): 956-72.

Bun, Maurice J., and Theresa D. Harrison. 2014. "OLS and IV Estimation of Regression Models including Endogenous Interaction Terms.” Discussion paper. University of Amsterdam.

Callaghy, Thomas M. 1989. "Toward State Capability and Embedded Liberalism in the Third World: Lessons for Adjustment." Pp. 115-38 in Fragile Coalitions: The Politics of Economic Adjustment, edited by Joan M. Nelson. New Brunswick, N.J.: Transaction.

Caraway, Teri, Stephanie Rickard, and Mark Anner. 2012. "International Negotiations and Domestic Politics: The Case of IMF Labor Market Conditionality." International Organization 66 (1): 27-61.

Cardoso, Fernando H. 2009. "New Paths: Globalization in Historical Perspective." Studies in Comparative International Development 44 (4): 296-317.

Cardoso, Fernando H., and Enzo Faletto. 1979. Dependency and Development in Latin America. Berkeley and Los Angeles: University of California Press. 
Centeno, Miguel A. 2002. Blood and Debt: War and the Nation-State in Latin America. University Park: Pennsylvania State University Press.

Charron, Nicholas, and Victor Lapuente. 2010. "Does Democracy Produce Quality of Government?" European Journal of Political Research 49 (4): 443-70.

Chase-Dunn, Christopher K. 1998. Global Formation: Structures of the World-Economy. Lanham, Md.: Rowman \& Littlefield.

Chorev, Nitsan. 2012. "Changing Global Norms through Reactive Diffusion: The Case of Intellectual Property Protection of AIDS Drugs." American Sociological Review $77: 831-53$.

Chwieroth, Jeffrey M. 2007. "Testing and Measuring the Role of Ideas: The Case of Neoliberalism in the International Monetary Fund." International Studies Quarterly 51 (1): 5-30.

Cingolani, Luciana, Kai Thomsson, and Denis de Crombrugghe. 2015. "Minding Weber More than Ever? The Impacts of State Capacity and Bureaucratic Autonomy on Development Goals.” World Development 72:191-207.

Copelovitch, Mark S. 2010. "Master or Servant? Common Agency and the Political Economy of IMF Lending." International Studies Quarterly 54 (1): 49-77.

Dahlström, Carl, Jan Teorell, Stefan Dahlberg, Felix Hartmann, et al. 2015. The QoG Expert Survey Dataset II. University of Gothenburg: Quality of Government Institute.

Daoud, Adel, and Bernhard Reinsberg. 2018. "Structural Adjustment, State Capacity and Child Health: Evidence from IMF Programmes." International Journal of Epidemiology. doi: 10.1093/ije/dyy251.

DiMaggio, Paul J., and Walter W. Powell, eds. 1991. The New Institutionalism in Organizational Analysis. Chicago: University of Chicago Press.

Djankov, Simeon, Jose G. Montalvo, and Marta Reynal-Querol. 2008. "The Curse of Aid." Journal of Economic Growth 13 (3): 169-94.

Dobbin, Frank, Beth Simmons, and Geoffrey Garrett. 2007. "The Global Diffusion of Public Policies: Social Construction, Coercion, Competition, or Learning?" Annual Review of Sociology 33:449-72.

Domhoff, G. William. 1990. The Power Elite and the State: How Policy Is Made in America. New York: de Gruyter.

Dos Santos, Theotonio. 1970. "The Structure of Dependence." American Economic Review 60 (2): 231-36.

Dreher, Axel. 2006. "IMF and Economic Growth: The Effects of Programs, Loans, and Compliance with Conditionality." World Development 34 (5): 769-88.

. 2009. "IMF Conditionality: Theory and Evidence." Public Choice 141 (1-2): 233-67.

Dreher, Axel, and Lars H. Siemers. 2009. "The Nexus between Corruption and Capital Account Restrictions." Public Choice 140 (1-2): 245-65.

Dreher, Axel, Jan-Egbert Sturm, and James R. Vreeland. 2009. "Global Horse Trading: IMF Loans for Votes in the United Nations Security Council." European Economic Review 53 (7): 742-57.

Dreher, Axel, and Roland Vaubel. 2004. "The Causes and Consequences of IMF Conditionality." Emerging Markets Finance and Trade 40 (3): 26-54.

Dreher, Axel, and Stefanie Walter. 2010. "Does the IMF Help or Hurt? The Effect of IMF Programs on the Likelihood and Outcome of Currency Crises." World Development 38 (1): 1-18.

Drori, Gili S., and John W. Meyer. 2006. "Scientization: Making a World Safe for Organizing." Pp. 31-52 in Globalization and Organization: World Society and Organizational Change, edited by Gili S. Drori, John W. Meyer, and H. Hwang. Oxford: Oxford University Press.

Easterly, William. 2005. "What Did Structural Adjustment Adjust?" Journal of Development Economics 76 (1): 1-22. 


\section{American Journal of Sociology}

Etzion, Dror, and Gerard F. Davis. 2008. "Revolving Doors? A Network Analysis of Corporate Officers and U.S. Government Officials." Journal of Management Inouirv 17 (3): $157-61$.

European Bank for Reconstruction and Development and World Bank. 2016. EBRDWorld Bank Business Environment and Enterprise Performance Survey. http://data .worldbank.org/data-catalog/BEEPS. Accessed July 27, 2016.

Evans, Peter B. 1979. Dependent Development: The Alliance of Multinational, State, and Local Capital in Brazil. Princeton, N.J.: Princeton University Press.

1995. Embedded Autonomy: States and Industrial Transformation. Princeton, N.J.: Princeton University Press.

- 1998. "Transferable Lessons? Re-examining the Institutional Prerequisites of East Asian Economic Policies.” Journal of Development Studies 34 (6): 66-86.

Evans, Peter B., and James E. Rauch. 1999. "Bureaucracy and Growth." American Sociological Review 64 (5): 748-65.

Evans, Peter B., and William H. Sewell. 2013. "The Neoliberal Era: Ideology, Policy, and Social Effects." Pp. 35-68 in Social Resilience in the Neoliberal Era, edited by P. A. Hall and M. Lamont. Cambridge: Cambridge University Press.

Fortin-Rittberger, Jessica. 2014. "Exploring the Relationship between Infrastructural and Coercive State Capacity." Democratization 21 (7): 1244-64.

Fourcade-Gourinchas, Marion, and Sarah L. Babb. 2002. "The Rebirth of the Liberal Creed: Paths to Neoliberalism in Four Countries." American Journal of Sociology 108 (3): 533-79.

Frank, Andre G. 1967. Capitalism and Underdevelopment in Latin America, vol. 93. New York: New York University Press.

Frank, David John, Wesley Longhofer, and Evan Schofer. 2007. "World Society, NGOs and Environmental Policy Reform in Asia." International Journal of Comparative Sociology 48 (4): 275-95.

Geddes, Barbara. 1994. Politician's Dilemma: Building State Capacity in Latin America. Berkeley and Los Angeles: University of California Press.

Gellner, Ernest. 1983. Nationalism and the Two Forms of Cohesion in Complex Societies. London: British Academy.

Gleditsch, Nils Petter, Peter Wallensteen, Mikael Eriksson, Margareta Sollenberg, and Havard Strand. 2002. “Armed Conflict, 1946-2001: A New Dataset.” Journal of Peace Research 39 (5): 615-37.

Gorski, Philip S. 1993. "The Protestant Ethic Revisited: Disciplinary Revolution and State Formation in Holland and Prussia." American Journal of Sociology 99 (2): 265-316.

Gould, Erica R. 2003. "Money Talks: Supplementary Financiers and International Monetary Fund Conditionality.” International Organization 57 (3): 551-86.

Grindle, Merilee S. 2004. "Good Enough Governance: Poverty Reduction and Reform in Developing Countries.” Governance 17 (4): 525-48.

Haggard, Stephan, and Robert R. Kaufman. 1989. "The Politics of Stabilization and Structural Adjustment." Pp. 209-54 in Developing Country Debt and Economic Performance, Vol. 1, The International Financial System. Edited by Jeffrey D. Sachs. Chicago: University of Chicago Press.

1992. The Politics of Economic Adjustment: International Constraints, Distributive Conflicts, and the State. Princeton, N.J.: Princeton University Press.

Halliday, Terence C., and Bruce G. Carruthers. 2007. "The Recursivity of Law: Global Norm Making and National Lawmaking in the Globalization of Corporate Insolvency Regimes." American Journal of Sociology 112 (4): 1135-1202.

2009. Bankrupt: Global Lawmaking and Systemic Financial Crisis. Stanford, Calif.: Stanford University Press.

Hamm, Patrick, Lawrence P. King, and David Stuckler. 2012. "Mass Privatization, State Capacity, and Economic Growth in Post-Communist Countries." American Sociological Review 77 (2): 295-324. 
Hanley, Eric, Lawrence P. King, and István J. Tóth. 2002. "The State, International Agencies, and Property Transformation in Postcommunist Hungary." American Journal of Sociology 108:129-67.

Harper, Charles, and Monica Snowden. 2017. Environment and Society: Human Perspectives on Environmental Issues. London: Taylor \& Francis.

Hayter, Teresa. 1971. Aid as Imperialism. Harmondsworth: Penguin.

Hechter, Michael. 2000. Containing Nationalism. Oxford: Oxford University Press.

Hendrix, Cullen S. 2010. "Measuring State Capacity: Theoretical and Empirical Implications for the Study of Civil Conflict." Journal of Peace Research 47 (3): 273-85.

Henisz, Witold J., Benet A. Zelner, and Mauro F. Guillén. 2005. "The Worldwide Diffusion of Market-Oriented Infrastructure Reform, 1977-1999.” American Sociological Review 70 (6): 871-97.

Hironaka, Ann. 2014. Greening the Globe: World Society and Environmental Change. Cambridge: Cambridge University Press.

Humphreys, Marcatan. 2005. "Natural Resources, Conflict, and Conflict Resolution Uncovering the Mechanisms." Journal of Conflict Resolution 49 (4): 508-37.

Hwang, Hokyu. 2006. "Planning Development: Globalization and the Shifting Locus of Planning." Pp. 69-90 in Globalization and Organization: World Society and Organizational Change. New York: Oxford University Press.

IMF (International Monetary Fund). 1995. "Republic of Armenia: Stand-By Arrangement (EBS/95/100).” IMF, Washington, D.C.

. 1996. "Republic of Georgia: Enhanced Structural Adjustment Arrangement (EBS/96/21).” IMF, Washington, D.C.

. 2000. "Bulgaria: Staff Report for the 1999 Article IV Consultation and Third Review under the Extended Arrangement (EBS/00/45)." IMF, Washington, D.C.

. 2001a. "Structural Conditionality in Fund-Supported Programs." IMF, Washington, D.C.

. 2001b. "Trade Policy Conditionality in Fund-Supported Programs." International Monetary Fund, Policy Development and Review Department, February 16. https:// www.imf.org/external/np/pdr/cond/2001/eng/trade/index.htm (accessed February 1, 2017).

- 2014. "Press Release: IMF Executive Board Approves €1.2 Billion Stand-by Arrangement for with Serbia.” IMF, Washington, D.C. https://www.imf.org/en/News /Articles/2015/09/14/01/49/pr1567.

Jones, Sam, and Finn Tarp. 2016. “Does Foreign Aid Harm Political Institutions?” Journal of Development Economics 118:266-81.

Karataşlı, Şahan S. 2017. "The Capitalist World-Economy in the Longue Durée." Sociology of Development 3 (2): 163-96.

Kaufmann, Daniel, Aart Kraay, and Massimo Mastruzzi. 2008. "Governance Matters VII: Aggregate and Individual Governance Indicators, 1996-2007.” Policy Research paper no. 4654. World Bank, Washington, D.C.

Keele, Luke, and Nathan J. Kelly. 2005. "Dynamic Models for Dynamic Theories: The Ins and Outs of Lagged Dependent Variables." Political Analvsis 14 (2): 186-205.

Kentikelenis, Alexander E. 2017. "Structural Adjustment and Health: A Conceptual Framework and Evidence on Pathways." Social Science and Medicine 187:296-307.

- 2018. "The Social Aftermath of Economic Disaster: Karl Polanyi, Countermovements in Action, and the Greek Crisis." Socio-Economic Review 16 (1): 39-59.

Kentikelenis, Alexander E., Lawrence P. King, Martin McKee, and David Stuckler. 2015. "The International Monetary Fund and the Ebola Outbreak." Lancet Global Health 3 (2): 69-70.

Kentikelenis, Alexander E., and Leonard Seabrooke. 2017. "The Politics of World Polity: Script-Writing in International Organizations." American Sociological Review 82 (5): 1065-92. 


\section{American Journal of Sociology}

Kentikelenis, Alexander E., Thomas H. Stubbs, and Lawrence P. King. 2016. "IMF Conditionality and Development Policy Space, 1985-2014." Review of International Political Economv 23 (4): 543-82.

Kentor, Jeffrey. 1981. "Structural Determinants of Peripheral Urbanization: The Effects of International Dependence.” American Sociological Review 46 (2): 201-11.

Keynes, John M. 1943. "Proposals for an International Clearing Union.” International Monetary Fund, Washington, D.C. http://imsreform.imf.org/reserve/pdf/keynesplan.pdf.

Khan, Mohsin S., and Malcom D. Knight. 1983. "Determinants of Current Account Balances of Non-oil Developing Countries in the 1970s: An Empirical Analysis." Staff Papers 30 (4): 819-42.

Kiely, Ray. 1998. "Neoliberalism Revised? A Critical Account of World Bank Conceptions of Good Governance and Market Friendly Intervention." International Journal of Health Services 28 (4): 683-702.

King, Lawrence P., and Aleksandra Sznajder. 2006. "The State-Led Transition to Liberal Capitalism: Neoliberal, Organizational, World-Systems, and Social Structural Explanations of Poland's Economic Success." American Journal of Sociology 112:751-801.

Kohli, Atul. 2004. State-Directed Development: Political Power and Industrialization in the Global Periphery. Cambridge: Cambridge University Press.

Krasner, Stephen D., and Thomas Risse. 2014. "External Actors, State-Building, and Service Provision in Areas of Limited Statehood: Introduction.” Governance 27 (4): 545-67.

Krueger, Anne O. 1974. "The Political Economy of the Rent-Seeking Society." American Economic Review 64 (3): 291-303.

Kurtz, Marcus J., and Andrew Schrank. 2007. "Growth and Governance: Models, Measures, and Mechanisms." Journal of Politics 69 (2): 538-54.

Lang, Valentin F. 2016. "The Democratic Deficit and Its Consequences: The Causal Effect of IMF Programs on Income Inequality." Paper presented at the Political Economy of International Organizations, Salt Lake City, January 7-9.

Lektzian, David, and Brandon Prins. 2008. "Taming the Leviathan: Examining the Impact of External Threat on State Capacity." Journal of Peace Research 45 (5): 613-31.

Leys, Colin. 1975. Underdevelopment in Kenya: The Political Economy of Neo-Colonialism, 1964-1971. Nairobi: East African Educational Publishers.

Li, Xue, and Alexander Hicks. 2016. "World Polity Matters: Another Look at the Rise of the Nation-State across the World, 1816 to 2001." American Sociological Review 81 (3): 596-607.

Longhofer, Wesley, Evan Schofer, Natasha Miric, and David John Frank. 2016. "NGOs, INGOs, and Environmental Policy Reform, 1970-2010.” Social Forces 94 (4): 1743-68.

Mann, Michael. 1986. The Sources of Social Power: A History of Power from the Beginning to A.D. 1760. Cambridge: Cambridge University Press.

. 1995. "A Political Theory of Nationalism and Its Excesses.” Pp. 44-64 in Notions of Nationalism, edited by Sukumar Periwal. New York: Central European University Press.

Marshall, Monty, Ted Gurr, and Keith Jaggers. 2015. "Polity IV Project: Political Regime Characteristics and Transitions, 1800-2014." Center for Systemic Peace, Vienna, Va.

Mazzucato, Mariana. 2015. The Entrepreneurial State: Debunking Public vs. Private Sector Myths. New York: Public Affairs.

McDonnell, Erin N. 2017. "Patchwork Leviathan: How Pockets of Bureaucratic Governance Flourish within Institutionally Diverse Developing States." American Sociological Review 82 (3): 476-510.

Merton, Robert K. 1987. "Three Fragments from a Sociologist's Notebooks: Establishing the Phenomenon, Specified Ignorance, and Strategic Research Materials." Annual Review of Sociology 13 (1): 1-29. 
Meyer, John W., John Boli, George M. Thomas, and Francisco O. Ramirez. 1997. "World Society and the Nation-State." American Journal of Sociology 103 (1): 144-81.

Mitra, Pritha, Amr Hosny, Gohar Minasyan, Mark Fischer, et al. 2016. "Avoiding the New Mediocre: Raising Long-Term Growth in the Middle East and Central Asia.” IMF Departmental paper 16/1. International Monetary Fund, Washington, D.C.

Mizruchi, Mark S. 2016. "The Resurgence of Elite Research: Promise and Prospects." Sociologica 10 (2): 1-10.

Montinola, Gabriella R., and Robert W. Jackman. 2002. "Sources of Corruption: A Cross-Country Study.” British Journal of Political Science 32 (1): 147-70.

Morgan, Stephen L., and Christopher Winship. 2007. Counterfactuals and Causal Inference: Methods and Principles for Social Research. Cambridge: Cambridge University Press.

Moss, Todd J., Gunilla Pettersson, and Nicholas van de Walle. 2006. "An Aid-Institutions Paradox? A Review Essay on Aid Dependency and State Building in Sub-Saharan Africa." Working paper 74. Center for Global Development.

Moyo, Dambisa. 2009. Dead Aid: Why Aid Is Not Working and How There Is a Better Way for Africa. New York: Farrar, Straus \& Giroux.

Nelson, Stephen C. 2014. "Playing Favorites: How Shared Beliefs Shape the IMF's Lending Decisions." International Organization 68 (2): 297-328.

Nistotskaya, Marina, and Luciana Cingolani. 2016. "Bureaucratic Structure, Regulatory Quality, and Entrepreneurship in a Comparative Perspective: Cross-Sectional and Panel Data Evidence." Journal of Public Administration Research and Theory 26 (3): 519-34.

Nooruddin, Irfan, and Joel W. Simmons. 2006. "The Politics of Hard Choices: IMF Programs and Government Spending.” International Organization 60 (4): 1001-33.

Nowzad, Bahram. 1981. The IMF and Its Critics. Essays in International Finance 146. Princeton, N.J.: Princeton University Press.

Nunn, Nathan, and Nancy Qian. 2014. "US Food Aid and Civil Conflict.” American Economic Review 104 (6): 1630-66.

Panitch, Leo, and Sam Gindin. 2012. The Making of Global Capitalism. London: Verso.

Pinheiro, Diogo, Jeffrey M. Chwieroth, and Alexander Hicks. 2015. "Do International Non-governmental Organizations Inhibit Globalization? The Case of Capital Account Liberalization in Developing Countries." European Journal of International Relations 21 (1): 146-70.

Polak, Jacques J. 1991. "The Changing Nature of IMF Conditionality.” Organization for Economic Cooperation and Development, Paris.

PRS Group. 2015. "International Country Risk Guide.” PRS Group, East Syracuse, N.Y. https://www.prsgroup.com/about-us/our-two-methodologies/icrg.

Przeworski, Adam, and James R. Vreeland. 2000. "The Effect of IMF Programs on Economic Growth.” Journal of Development Economics 62:385-421.

Reinsberg, B., T. Stubbs, A. Kentikelenis, and L. King. 2019. "The Political Economy of Labor Market Deregulation during IMF Interventions.” International Interactions, forthcoming.

Rodrik, Dani. 2014. "Getting Institutions Right.” DICE report no. 2. CESifo, Munich. . 2014. "Green Industrial Policy." Oxford Review of Economic Policy 30 (3): 469-91.

Rodrik, Dani, Arvind Subramanian, and Francesco Trebbi. 2004. "Institutions Rule: The Primacy of Institutions over Geography and Integration in Economic Development." Journal of Economic Growth 9 (2): 131-65.

Roodman, David. 2011. "Fitting Fully Observed Recursive Mixed-Process Models with CMP.” Stata Journal 11 (2): 159-206.

Ross, Michael L. 2013. "Oil and Gas Data, 1932-2011.” Harvard University Dataverse.

Rothstein, Bo, and Jan Teorell. 2012. "Defining and Measuring Quality of Government." Pp. 6-26 in Good Government: The Relevance of Political Science, edited by Sören Holmberg and Bo Rothstein. Cheltenham: Elgar. 


\section{American Journal of Sociology}

Sassen, Saskia. 2014. Expulsions: Brutality and Complexity in the Global Economy. Cambridge, Mass.: Belknap.

Savoia, Antonio, and Kunal Sen. 2015. "Measurement, Evolution, Determinants, and Consequences of State Capacity: A Review of Recent Research." Journal of Economic Surveys 29 (3): 441-58.

Schofer, Evan, and Ann Hironaka. 2005. "The Effects of World Society on Environmental Protection Outcomes." Social Forces 84 (1): 25-47.

Schofer, Evan, Ann Hironaka, David John Frank, and Wesley Longhofer. 2012. "Sociological Institutionalism and World Society." Pp. 57-68 in The Wiley-Blackwell Companion to Political Sociology, edited by E. Amenta, K. Nash, and A. Scott. Oxford: Wiley-Blackwell.

Seabrooke, Leonard, and Lasse F. Henriksen, eds. 2017. Professional Networks in Transnational Governance. Cambridge: Cambridge University Press.

Seabrooke, Leonard, and Eleni Tsingou. 2014. "Distinctions, Affiliations, and Professional Knowledge in Financial Reform Expert Groups.” Journal of European Public Policv 21 (3): 389-407.

Shandra, John M., Jenna Nobles, Bruce London, and John B. Williamson. 2004. "Dependency, Democracy, and Infant Mortality: A Quantitative, Cross-National Analysis of Less Developed Countries." Social Science and Medicine 59 (2): 321-33.

Sklair, Leslie. 2001. The Transnational Capitalist Class. Oxford: Blackwell.

Skocpol, Theda. 1979. States and Social Revolutions: A Comparative Analysis of France, Russia and China. Cambridge: Cambridge University Press.

Smelser, Nicholas. 1964. Toward a Theory of Modernization. New York: Basic.

Staiger, Douglas, and James H. Stock. 1997. "Instrumental Variables Regression with Weak Instruments." Econometrica 65 (3): 557-86.

Stock, James H., and Motohiro Yogo. 2005. "Testing for Weak Instruments in Linear IV Regression." In Identification and Inference for Econometric Models: Essays in Honor of Thomas Rothenberg, edited by Donald W. K. Andrews, James H. Stock, and Thomas J. Rothenberg. Cambridge: Cambridge University Press.

Stone, Randall W. 2002. Lending Credibilitv: The International Monetarv Fund and the Post-Communist Transition. Princeton, N.J.: Princeton University Press.

Stubbs, Thomas H. 2015. "Ethnopolitics and the Military in Kenya." Pp. 69-88 in Forging Military Identity in Culturally Pluralistic Societies: Quasi-Ethnicity, edited by D. Zirker. Lanham, Md.: Lexington.

Stubbs, Thomas H., and Alexander Kentikelenis. 2017. "International Financial Institutions and Human Rights: Implications for Public Health." Public Health Reviews 38 (1): 27. 2018. "Targeted Social Safeguards in the Age of Universal Social Protection: The IMF and Health Systems of Low-Income Countries." Critical Public Health 28 (2): 132-39.

Stubbs, Thomas, Alexander Kentikelenis, David Stuckler, Martin McKee, et al. 2017. "The Impact of IMF Conditionality on Government Health Expenditure: A CrossNational Analysis of 16 West African Nations. Social Science and Medicine 174:220-27. https://doi.org/10.1016/j.socscimed.2016.12.016.

Stubbs, Thomas H., Lawrence P. King, and David Stuckler. 2014. "Economic Growth, Financial Crisis, and Property Rights: Observer Bias in Perception-Based Measures." International Review of Applied Economics 28 (3): 401-18.

Stubbs, Thomas, Bernhard Reinsberg, Alexander Kentikelenis, and Lawrence King. 2018. "How to Evaluate the Effects of IMF Conditionality: An Extension of Quantitative Approaches and an Empirical Application to Public Education Spending." Review of International Organizations. doi: 10.1007/s11558-018-9332-5.

Summers, Lawrence H., and Lant H. Pritchett. 1993. "The Structural-Adjustment Debate." American Economic Review 83 (2): 383-89.

Tanzi, Vito. 1998. "Corruption around the World: Causes, Consequences, Scope, and Cures." Staff Papers 45 (4): 559-94. 
Teorell, Jan. 2015. "A Quality of Government Peace? Explaining the Onset of Militarized Interstate Disputes, 1985-2001.” International Interactions 41 (4): 648-73.

Teorell, Jan, S. Dahlberg, S. Holmberg, B. Rothstein, A. Khomenko, and R. Svensson. 2016. The Quality of Government Standard Dataset, version Jan16. University of Gothenburg, Quality of Government Institute. http://www.qog.pol.gu.se. Accessed March 30, 2016.

Thacker, Strom C. 1999. "The High Politics of IMF Lending.” World Politics 52 (1): 38-75.

Thies, Cameron G. 2010. "Of Rulers, Rebels, and Revenue: State Capacity, Civil War Onset, and Primary Commodities.” Journal of Peace Research 47 (3): 321-32.

Tilly, Charles. 1990. European States, AD 990-1990. Cambridge: Blackwell.

Toye, John. 1994. "Structural Adjustment: Context, Assumptions, Origin and Diversity." In Structural Adjustment and beyond in Sub-Saharan Africa: Research and Policy Issues, edited by Rolph van der Hoeven and F. P. M. van der Kraaij. Hague: Ministry of Foreign Affairs.

Van Rijckeghem, Caroline, and Beatrice Weder. 2001. "Bureaucratic Corruption and the Rate of Temptation: Do Wages in the Civil Service Affect Corruption, and by How Much?" Journal of Development Economics 65 (2): 307-31.

Vreeland, James R. 2003. The IMF and Economic Development. Cambridge: Cambridge University Press.

- 2007. The International Monetary Fund: Politics of Conditional Lending. London: Routledge.

Wade, Robert H. 1990. Governing the Market: Economic Theory and the Role of Government in East Asian Industrialization. Princeton, N.J.: Princeton University Press. . 2001. "Capital and Revenge: The IMF and Ethiopia." Challenge 44 (5): 67-75. . 2002. "US Hegemony and the World Bank: The Fight over People and Ideas." Review of International Political Economy 9 (2): 215-43.

Wallerstein, Immanuel. 1974. "The Rise and Future Demise of the World Capitalist System: Concepts for Comparative Analysis." Comparative Studies in Society and History 16 (4): $387-415$.

. 1979. The Capitalist World-Economy, vol. 2. Cambridge: Cambridge University Press.

Walton, John, and Charles Ragin. 1990. "Global and National Sources of Political Protest: Third World Responses to the Debt Crisis." American Sociological Review 55:876-90.

Waterbury, John. 1992. "The Heart of the Matter? Public Enterprise and the Adjustment Process." Pp. 182-220 in The Politics of Economic Adjustment: International Constraints, Distributive Conflicts, and the State, edited by Stephan Haggard and Robert R. Kaufman. Princeton, N.J.: Princeton University Press.

Weber, Max. 1930. The Protestant Ethic and the Spirit of Capitalism. Translated by Talcott Parsons with a foreword by R. T. Tawney. London: Allen \& Unwin.

-1978. Economy and Society: An Outline of Interpretive Sociology. Berkeley and Los Angeles: University of California Press.

Wedel, Janine R. 1998. Collision and Collusion: The Strange Case of Western Aid to Eastern Europe. New York: St. Martin's.

Williamson, John. 1990. "What Washington Means by Policy Reform." In Latin American Adjustment: How Much Has Happened? Washington, D.C.: Institute for International Economics.

Woo, Byungwon. 2013. "Conditional on Conditionality: IMF Program Design and Foreign Direct Investment.” International Interactions 39 (3): 292-315.

World Bank. 2015. "World Development Indicators.” World Bank, Washington, D.C. http://data.worldbank.org.

— 2016. "Harmonized List of Fragile Situations." World Bank, Washington, D.C. http://www.worldbank.org/en/topic/fragilityconflictviolence/brief/harmonized-list-of -fragile-situations. 